\title{
LA ACTITUD DE CLEMENTE DE ALEJANDRIA ANTE LA RIQUEZA
}

\author{
Juan de Churruca \\ Profesor emérito de la Universidad de Deusto
}

\section{El problema pobreza-riqueza}

Se puede decir que en principio existe un consenso universal en que la pobreza es mala. Es la valoración predominante en la literatura griega y latina, que aparece también explícitamente formulada en los libros sapienciales del Antiguo Testamento. Incluso en los escritos en que más fuertemente se censura a los ricos y se ensalza a los pobres, se está afirmando indirectamente que a los ricos se les censura por haber explotado a los pobres y haberles llevado a una situación de miseria e indefensión (la pobreza), considerada como mala e injusta ${ }^{1}$. Sin embargo, a lo largo de la historia han ido apareciendo matizaciones y correcciones de ese principio general. La riqueza puede llevar a la autocomplacencia, a la autosuficiencia egoísta, al desinterés por problemas que trascienden lo material, a un ansia creciente y absorbente de seguir enriqueciéndose ${ }^{2}$. El afán de enriquecerse puede llevar y lleva con frecuencia a no reparar en la calidad moral de los medios utilizados para ello, y por consiguiente a cometer claras injusticias. De ahí que en textos legales del pueblo de Israel se castigue la injusticia y los abusos de los

1 Sobre los conceptos de pobreza y riqueza, sus efectos y su valoración en general: R. SÈvE, «Pauvreté»: EPU 2/2, 1884; F. GIROUX, «Pauperisme»: EPU 2/2, 1883; C. BAUER, «Armut»: Staatslexikon (Friburgo 1957-1970) 1, 581-588; G.E.M. DE STE Croix, The Class Struggle in the Ancient World (Londres 1981) 425-426.

2 Por lo que se refiere a estas ideas en la cultura griega y en las diversas épocas de la historia del pueblo de Israel, ver: H. BolKENSTEIN, «Armut»: RAC 1, 689-701; A. KALSBACH, «Armut»: RAC 1, 701-702; E. KUTSCH, «Armut»: RGG ${ }^{3}$ 1, 622-623; R. BOGAERT, «Geld»: RAC 9, 824-829; (H.L. Strack)-P. BilleRBECK, Kommentar zum Neuen Testament aus Talmud und Midrasch $1^{9}$ (Munich 1989) 818-826; F. HAUCK-KASCH, «ா入ouToS»: TWNT 6, 317-324. Particularmente expresivo es en este sentido es: Sir 13, 4-8; 31, 1-7. 
ricos y que en la literatura sapiencial se aconseje un uso moderado y justo de la riqueza ${ }^{3}$.

La desigualdad social entre la minoría rica y la mayoría pobre y explotada puede ser tan flagrante e injusta, que dé lugar a que en determinadas coyunturas históricas surja una crítica social muy dura. Es el caso de muchos de los grandes profetas de Israel (Isaías, Jeremías, Ezequiel, Malaquías, Miqueas, etc.), que en los siglos VIII al vi a.C. fustigaron con gran dureza los abusos e injusticias de $\operatorname{los}$ ricos$^{4}$. En muchos casos los Profetas generalizaron su crítica de tal forma que al leer sus obras parece presumirse que el rico es injusto mientras no se demuestre lo contrario $^{5}$. De forma simétrica, en los escritos de los Profetas y sobre todo en los Salmos, aparece una sublimación de los pobres, a los que se presenta junto a otros marginados (huérfanos, viudas, etc.) como víctimas de la operación y abuso de los poderosos, como desprovistos de toda la ayuda terrena y abocados a poner su única esperanza en Yavé ${ }^{6}$. Surge así lo que se ha dado en llamar la «mística de la pobreza», que presenta a los pobres como los predilectos de Yavé porque se han puesto en sus manos, y Yavé acabará haciéndoles justicia. Por el contrario, los ricos y poderosos han sido infieles a Yavé, han oprimido a los pobres y serán castigados. En esta mística de la pobreza hay una clara referencia escatológica al anunciar la futura intervención justiciera de Yavé, aunque sin precisar cuándo se producirá ni presentarla como inminente 7 .

Aunque desde la época de los grandes Profetas (VIII-VI a.C.) hasta la de Jesús habían transcurrido por lo menos cinco siglos, la situación de injusta desigualdad social no había mejorado: la diferencia entre el «pueblo de la tierra» de las pequeñas aldeas de Galilea al que predominantemente se dirigió la predicación de Jesús, y la minoría rica, seguía siendo muy grande. A ello hay que añadir otros factores que contribuyeron sin duda a potenciar la sensibilidad para percibir la desigualdad. Por una parte las turbulencias políticas subsiguientes a la conquista romana aceptada por la minoría económicamente fuerte de los saduceos

3 Sobre este punto: J.L. SiCRE, Con los pobres de la tierra: la justicia social en los Profetas de Israel (Madrid 1985) 57-62. Pasajes particularmente significativos: Ex 22, 20-25; 23, 6; Dtn 15, 7-11; Sir 13, 4; 34, 25-29.

4 Algunos ejemplos destacados: Am 5, 10-12; 8, 4-10; Is 5, 8-10; 10, 1-4; Jer 2, 34; 5 , 26-29, Ez 22-29; Mich 2, 1-5; 6, 9-16; Mal 3, 5; 21, 7. Ver: Sicre [n 3] passim y conclusiones (437-453).

5 SICRE [n 3] 448-453.

6 R. MARTín-AchaRd, «'nh»: THAT 2, 348-350; D. Michel, «Armut»: TRE 4, 74-76.

7 Sobre la mística de la pobreza: M. DiBelius, Der Brief des Jakobus ${ }^{10}$ (Gotinga 1959) 37-44; F. Mussner, Der Jakobustrief (Regensburg 1978) 76-84; DE STE CroIX, Class Struggle [n 1] 430-434. 
y mal vista por el pueblo. Por otra parte, surgieron movimientos liderados por profetas que vivían en extrema pobreza, y predicaban la penitencia a la vista de una próxima catástrofe escatológica. Aparecieron también grupos que practicaban un ascetismo riguroso, en algunos casos con comunidad de bienes. En determinados grupos nació o creció una inquietud apocalíptica. Hubo varios movimientos mesiánicos fracasados por sí mismos o sofocados por los romanos ${ }^{8}$.

En ese ambiente actuó Jesús. Había vivido probablemente de su trabajo de artesano en un pequeño pueblo de Galilea hasta que en un momento determinado lo dejó todo para dedicarse plenamente a anunciar el Reino de Dios y su inminente llegada. Su predicación se dirigió preferentemente al pueblo llano de cultura rural y artesana. La ética que enseñaba era de una gran sinceridad libre de formalismos y compromisos. El amor al prójimo era uno de los puntos fundamentales de su predicación. Su sensibilidad para la injusticia que padecían los pobres y su simpatía por los oprimidos era clara. Su forma de hablar era directa, valiente, gráfica, nada académica, rica en máximas, con comparaciones, hipérboles y paradojas que servían para poner de relieve ante su público rural los principios éticos y religiosos que quería comunicar. En gran parte de su predicación estaba presente la idea de la inminencia de la catástrofe escatológica que precedería inmediatamente a la plena implantación del Reino de Dios, que ya había comenzado a irrumpir. Le acompañaba un pequeño grupo de seguidores entusiastas que habían renunciado a sus bienes temporales y a su vida profesional, pero sin practicar un ascetismo rígido. Entre sus adictos y simpatizantes hubo también personas económicamente acomodadas que no renunciaron a sus bienes ${ }^{9}$. En este ambiente de tensión, de entusiasmo y entrega, de esperanza y temor escatológicos ha de entenderse la perícopa del Evangelio (Mc 10, 17-31) que Clemente en un ambiente muy distinto tomó como base de su opúsculo sobre la posibilidad de salvación de los ricos, que es el objeto principal de este estudio.

8 Sobre la situación de Palestina en el aspecto político-social en la época de Jesús: E. Schürer-G. Vermes-F. Millar, The History of the Jewish People in the Age of Jesus Christ 2 (Edimburgo 1979) 656-667; S. APLEBAUM, «Economic Life in Palestina», en: S. SAFRAI-A. STERN (ed), The Jewish People 2 (Assen-Filadelfia 1976) 565-667; G. VERMES, Jesus the Jew (Londres, ed Fontana 1976) 42-82; G. THEISSEN, «Wir haben alles verlassen»: NovTest 19 (1977) 194-196.

9 Sobre la orientación de la predicación de Jesús: C. PERrot, Jésus et l'histoire (Paris 1979) 171-200: VeRMES [n 8] 86-102; M. HENGEL, Eigentum und Reichtum in der frühen Kirche (Stuttgart 1973) 31-36; E. BAMmEL, $\pi \tau \omega \chi \mathrm{OOS}$ : TWNT 6, 902-908; G.E.M. DE STE CRoIX, «Early Christian Attittudes to Property and Slavery»: SCH 12 (1975) 1-9; J. DuPONT, Les béatitudes (Brujas 1954) 142-148; C. BURCHARD, «Jesus von Nazareth», en: J. BECKER (ed), Die Anfänge des Christentums (Stuttgart 1987) 20-50. 
En las comunidades cristianas de épocas posteriores se aprecian diversas actitudes antes el problema riqueza-pobreza. Entre los judeocristianos hubo algún grupo que practicó al menos durante algún tiempo la comunidad de bienes, aunque tal actitud debió de ser una excepción ${ }^{10}$. En muchas comunidades debió de ser frecuente la visita o estancia de misioneros itinerantes (apóstoles, maestros, profetas) dedicados enteramente a su labor y mantenidos por la beneficencia de la comunidad ${ }^{11}$. En algunos lugares hubo grupos o individuos que practicaban un ascetismo rígido. Pero por otro lado, desde un principio se produjo la conversión al cristianismo de personas que se hallaban en situación económico-social acomodada, aunque el nivel medio de la mayoría de las comunidades cristianas fue durante mucho tiempo económicamente bajo, pero no ínfimo ${ }^{12}$. Además, hay que tener en cuenta varios fenómenos que influyeron en que, a lo largo del tiempo, cambiase notablemente el horizonte cultural de los destinatarios del mensaje cristiano y la problemática económico-social de las comunidades. En primer lugar la difusión del cristianismo se realizó predominantemente entre la población urbana, que aún en las pequeñas ciudades se diferenciaba notablemente en los aspectos económico, social y cultural de la población rural. Por otro lado, fue cada vez mayor el número de adeptos que no provenían del judaísmo y accedían al cristianismo con un bagaje de concepciones previas muy distinto del de los judeocristianos ${ }^{13}$. Finalmente el

10 La comunidad de bienes aparece en una descripción idealizada y generalizada de Act 4, 32-37; 5, 1-11. Sobre estos pasajes: A. WEISER, Die Apostelgeschichte 1 (GüterslohWürzburg 1981) 134-148. Sobre el tema en general: HENGEL [n 9] 39-45; M. WACHT, «Gütergemeinschaft»: RAC 13, 26-28; 52-54.

11 Sobre los misioneros itinerantes del primitivo cristianismo: A.v. HaRnack, Die Mission und Ausbreitung des Christentums in den drei ersten Jahrhunderten ${ }^{4}$ (Leipzig 1924) 332-379; G. KRETSCHMAR, «Ein Beitrag zur Frage nach dem Ursprung frühchristlicher Askese»: ZTK 61 (1964) reproducido en: K.S. FRANK (ed), Askese und Mönchtum in der alten Kirche (Darmstadt 1975) 135-156; G. KRETSCHMAR, «Das christliche Leben und die Mission in der frühen Kirche», en: H. Frohnes-U.W. KNORR (ed), Kirchengeschichte als Missiongeschichte 1 (Munich 1974) 94-100.

12 Sobre la existencia de personas económicamente bien situadas en las comunidades cristianas ya en los primeros siglos: HARNACK, Mission ${ }^{4}$ [n 11] 559-568; H. KREISIG, «Zur sozialen Zusammensetzung der frühchristlichen Gemeinden im ersten Jahrhundert unserer Zeit»: Eirene 6 (1967) 91-100.

13 Ver sobre este tema: DE STE CroIX, Attitudes [n 9] SCH 12 (1975) 9-11; H.J. DreXHAGE, «Wirtschaft und Handel in den frühchristlichen Gemeinden»: RQ 76 (1981) 7-72; W.A. MeEKs, The First Urban Christians (Londres 1983, 9-73, E.A. JudgE; The Social Pattern of Christian Groups in the Firsth Century (London 196) 49-61; H. KRAFT, Die Entstehung des Christentums ${ }^{3}$ (Darmstadt 1990) 248-279; P. LAMPE-U. LuZ, «Nachpaulinisches Christentum und pagane Gesellschaft», en: J. BECKER (ed), Die Anfänge des Christentums (Stuttgart 1987) 185-196; 207-216). 
sentimiento inicialmente muy extendido de que la catástrofe escatológica iba a producirse muy pronto, fue disipándose y quedó sustituido gradualmente por la idea de que podía producirse en cualquier momento, pero sin la convicción de que ese momento estaba muy cerca ${ }^{14}$. Con ello disminuyó indudablemente la sensación de lo perecedero e irrelevante de las cosas temporales. Con todo hay que tener también en cuenta que en algunos grupos y especialmente en determinados momentos de tensión y de persecución renacía la ardiente expectativa del fin muy cercano ${ }^{15}$.

Dentro de este marco histórico-cultural la actitud ante el problema pobreza-riqueza fue muy variada. Siguió habiendo grupos que descalificaban radicalmente a los ricos en tono parecido al que habían empleado los Profetas de Israel: un caso típico es la Carta de Jacobo escrita probablemente a finales del siglo I, incorporada tardíamente al canon del Nuevo Testamento, pero probablemente todavía no considerada como canónica en el ambiente de Clemente de Alejandría ${ }^{16}$. Había muchos que veían en la riqueza un gran peligro que alejaba casi necesariamente de Dios: es característica en este sentido la doctrina del Pastor de Hermas, escrito apocalíptico redactado en Roma hacia el año $150 \mathrm{y}$ tenido en alta estima por Clemente de Alejandría ${ }^{17}$. En la parénesis cristiana se exhortaba desde muy pronto a evitar que la desigualdad económico-social entre los miembros de la comunidad repercutiese en la vida religiosa de ésta, a saber: contentarse con lo suficiente para vivir frenando el ansia de enriquecerse, a la ayuda desinteresada a los miembros más necesitados ${ }^{18}$. En general cabe afirmar que la actitud ante la riqueza no era favorable en las comunidades cristianas en el último cuarto del siglo II. Y esa actitud tenía un fuerte apoyo en las condenas contenidas en numerosos pasajes tanto del Antiguo Testamento y

14 H. ConZelmann, «Eschatologie»: RGG33 2, 665-672, IDEM, «Parusie»: RGG ${ }^{3}$ 5, 130-132.

15 Sobre las tendencias y grupos apocalípticos durante los tres primeros siglos: A.v. HAR-

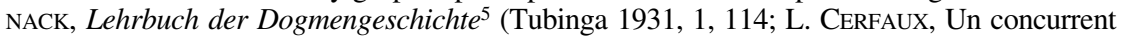
du christianisme (Tournai-París 1957) 388-391; P. VielHAUER-G. STRECKER, «Apokalypsen und Verwandtes», en NTApkr $2^{5}, 491-547$. Por lo que se refiere a la riqueza son particularmente significativos: Apc 18, 15-24; ApcPetr(gr) 30 // ApcPetr(aeth) 9 (NTApkr 25, 572-573).

16 Jac 2, 1-7. Sobre Jac: H. FrAnKemölle, Der Brief des Jakobus 1 (Gütersloh-Würzburg 1994) 20-120.

17 Herm, Vis 1, 1, 8; 2, 3, 1; 3, 6, 5-7; 3, 9, 5-6; 3, 11, 12; Mand 10, 1,4 ; Sim 1, 5; 1, 8, 9; 2,$10 ; 8,8,1-2 ; 8,9 ; 9,20,1-2$. Sobre el Pastor de Hermas: ViELHAUER-STRECKER [n 15] NTApkr $2^{5}, 537-547$. Sobre la alta estima en que Clemente tenía a Hermas: G. BARDY, La théologie de l'Église de Saint Irénée au Concile de Nicée (París 1947) 123-124.

18 Sobre ste punto: v. HaRnack, Mission ${ }^{4}$ [n 11] 170-216; Hengel, Eigentum [n 9] 6168. WACHT [n 10] RAC 13, 26-28. Ejemplos típicos: 1 Tim 6, 10; Polyc, Ep 4,1. 
de los Evangelios Sinópticos reconocidos como palabra de Dios. En comunidades como la de Alejandría, donde en esa época el grupo de cristianos en posición económica desahogada constituía ya una minoría importante, debió de plantearse el problema de si una situación económica acomodada era compatible con el cristianismo y en qué condiciones lo era. Ese es el problema con el que se enfrentó Clemente.

\section{Clemente de Alejandría}

Clemente había nacido probablemente en Atenas, de padres paganos, hacia el año 150. En fecha y lugar no conocidos se había convertido al cristianismo y como muchos jóvenes de su época había realizado numerosos viajes por Italia meridional, Siria y Palestina para oír a maestros cristianos afamados. Al llegar a Alejandría fijó allí su residencia atraído por las enseñanzas de Panteno ${ }^{19}$.

Alejandría en esa época seguía siendo una ciudad extraordinariamente floreciente, la segunda en importancia dentro del Imperio después de Roma, y culturalmente más importante en muchos aspectos que la capital. El judaísmo se había establecido sólidamente dentro de la ciudad y en él se había desarrollado una vigorosa tendencia de pensamiento que utilizaba la filosofía griega para explicar el Antiguo Testamento. En esa corriente destacó Filón (ca 10 a.C.-45 a 50 p.C.) cuyas obras influyeron notablemente en el pensamiento de Clemente ${ }^{20}$. No se sabe exactamente la fecha y la forma en que el cristianismo había penetrado en Alejandría. En la época de Clemente estaba sólidamente establecido. Además de la corriente que prevaleció como ortodoxa, hubo numerosas corrientes más o menos disidentes y diversos grupos gnósticos en los que ideas de origen cristiano se mezclaban con especulaciones filosóficas sincretistas ${ }^{21}$. En la comunidad cristiana existía una escuela para formación de los catecúmenos, en la que destacó Panteno, el admirado maestro de Clemente. Este le sucedió en la dirección de la escuela (Eus, HE 6,6) 22 .

19 Datos sobre Clemente en: B. Altaner-A. StuiBer, Patrologie 8 (Friburgo 1978) 190101; (W. SCHMID)-O. STÄHLIN, Geschichte der griechischen Literatur 2/26 (Munich $1924=$ 1961) $1.310-1.317$.

20 B. Schaller, «Philo 10»: KP 4, 772-776, K. Beyschlag, Grundriss der Dogmengeschichte $1^{2}, 210-212$.

${ }^{21}$ Sobre las escasas noticias acerca de la penetración y desarrollo inicial del cristianismo en Alejandría hasta la época de Clemente: HARnACK, Mission ${ }^{4}, 705-710$.

${ }^{22}$ Sobre los orígenes de la Escuela de Alejandría: Eus, HE 5, 10, 1-4; 6-6. Valoración crítica de la infonmación de Eusebio en: G. BARDY, «Aux origines de l'Ecole d'Alexandrie»: RSR 27 (1937) 65-83; BEYSCHLAG [n 20] 1², 210-212. 
Por lo que puede deducirse de la obra de Clemente, en la comunidad cristiana de Alejandría había al menos una importante minoría de personas económica y socialmente acomodadas y de notable grado de formación cultural ${ }^{23}$. Clemente debió de trabajar preferentemente con ellos y, en la doctrina que trató de transmitirles, aparecen unas series de rasgos muy característicos. Tuvo un marcado interés en conjugar el cristianismo con la cultura griega, en la que veía un logro cultural humano de gran calidad, procedente, en lo que tenía de bueno, de la comunicación parcial del Logos divino ${ }^{24}$. Las ideas filosóficas procedentes sobre todo del estoicismo, del platonismo medio y de Filón le ayudaron a estructurar su concepción antropológica y su ideal de perfección ético-religiosa cristina ${ }^{25}$. Conforme a ella el hombre conoce la base de la

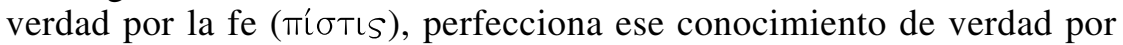
la profundización interna $(\gamma \nu \tilde{\omega} \sigma \iota s)$ en un continuo proceso de perfeccionamiento $(\tau \in \lambda \in \hat{l}(\omega \sigma \mathrm{\iota s})$ que tiende a culminar en la plena unión con Dios ( $\ddot{\epsilon} \nu \omega \sigma l s \quad \Theta \in \tilde{\omega})$. En ese proceso de perfeccionamiento es fundamental el esfuerzo continuo por desarraigar del alma las pasiones y apetencias $(\pi a ́ \theta \eta)$ que tienden a desviarla de su camino ${ }^{26}$. El ideal ético-religioso de Clemente es marcadamente intelectualista y elitista sin que ello implique desprecio por el vulgo. Clemente distingue abiertamente en la comunidad una mayoría que de hecho se contenta necesariamente con lo esencial, y una minoría selecta que ha adquirido la verdadera gnosis y ha alcanzado altos niveles en el continuo ascenso hacia la perfección. A esos gnósticos les corresponde una función orientativa

${ }^{23}$ H.I. MARrou, Clément d'Alexandrie, Le pédagogue 1 (París 1960) (SC70, 62-66; 86-91).

${ }^{24}$ Sobre el helenismo de Clemente: HARnACK, Dogmg 5 [n 15] 1, 642-649; M. PoHLEnZ, «Clemens von Alexandreia und sein hellenistisches Christentum»: NGött 1943/3, 103-180; C. MONDÉSERT, Clëment d'Alexandrie, Le protreptique (París 1949) (SC 2, 5-26); W. VöLKER, Der wahre Gnostiker nach Clemens Alexandrinus (Berlín 1957) (TU 57) passim; BEYSCHLAG [n 20] 12, 212-219.

25 Sobre el eclecticismo filosófico de Clemente: S. LiLla, Clement of Alexandria: a Study an Christian Platonism and Gnosticism (Oxford 1971) 61-117; 226-228; H. CHADwick, «Philo and the Beginnings of the Christian Thought», en A.H. Armstrong (ed), The Cambridge History of Later Greek and Early Medieval Philosophy (Cambridge 1967) 168-181. A.M. RitTER, «Christentum und Eigentum bei Klemens von Alexandrien auf dem Hintergrund der frühchristlichen Armenfrömmigkeit und der Ethik der kaiserlichen Stoa»: ZKG 86 (1975) 9-18 pone sobre todo de relieve las coincidencias de Clemente con los estoicos de la época imperial, principalmente con Séneca, y en cambio atenúa el influjo de la Estoa antigua y media.

26 Sobre el ideal de perfección de Clemente: J. MeIFort, Der Platonismus bei Clemens Alexandrinus (Tubinga 1928) 69-83; VÖLKER [n 24] 301-457; 508-515; 579-587; LILLA [n 25] 103-117. 
que no coincide con la gestión jerárquica ${ }^{27}$. De hecho Clemente probablemente nunca perteneció al clero ${ }^{28}$.

Clemente desarrolló una gran actividad en Alejandría hasta los años 202 ó 203, en que hubo de abandonar la ciudad para escapar de la persecución de Septimio Severo ${ }^{29}$. Se estableció en Capadocia, posiblemente en su capital, Cesarea, donde continuó sus actividades en un medio cultural menos elevado que el de Alejandría. Murió poco antes del año $215^{30}$.

Clemente dejó tres obras principales: el Protréptico o exhortación (a la conversión), en un solo libro; el Pedagogo, en tres libros, que es un conjunto de enseñanzas a los ya convertidos para actuar conforme a la verdad cristiana ante los diversos problemas y situaciones de la vida; y los Tapices (en griego $\Sigma \tau \rho \omega \mu a t \in \tilde{i}$ [Strom]), nombre con que se designaba a obras de carácter misceláneo en que se abordaban los más diversos problemas sin orden estrictamente sistemático: la obra de Clemente tiene $8 \operatorname{libros}^{31}$. La erudición de Clemente en las tres obras es amplísima; su estilo es desigual, a veces difícil por su esfuerzo de concisión; el tecnicismo de su vocabulario deja a veces que desear ${ }^{32}$.

Además de esas tres obras principales y de otras menores fragmentariamente conservadas y de otras perdidas, Clemente escribió un opúsculo que es el que interesa directamente en este estudio ${ }^{33}$. Ha pasado a la

27 Sobre la función del verdadero gnóstico en la comunidad cristiana según Clemente: VÖLKER [n 24] 546-557.

28 Sobre la probable no pertenencia de Clemente al clero: BARDY, Théologie [n 17] 111: H. КocH, «War Klemens von Alexandrien Priester?»: ZNW 20 (1921) 43-48.

${ }^{29}$ Datos sobre la persecución en tiempos de Septimio Severo en: Eus, HE 6, 1; K.H. ScHWARTE, «Das angebliche Christengesetz des Septimius Severus»: Historia 12 (1963) 185-208; M. SORDI, Il cristianesimo e Roma (Bolonia 1965) 217-231.

${ }^{30}$ Eus, HE 6, 11, 6; 6, 14, 9. Sobre la situación de cristianismo en Capadocia: v. HARNACK, Mission ${ }^{4}$ [n 11] 743-747; F. CUMONT, «The Frontier Provinces of the East»: CAH 11, 606-613.

31 Breve descripción de las tres principales obras de Clemente en: AltanER-StUiBer, [n 19] 192-193; BEYSCHLAG [n 20] 122, 216-218. Utilizo las siguientes ediciones: Protr ed C. Mondésert, SC 2 (París 1949); Paed ed H.I. Marrou-M. Harl, SC 70 (1960); 108 (1965); 158 (1970) (París); Strom ed O. SthÄLIN-L. FrüChTL, GCS 523 (Clem 2); $17^{2}$ (Clem 3). Para la matización de la terminología empleada por Clemente es sumamente útil: O. STÄHLIN, Register: GCS 39 (Clem 4) (Leipzig 1936).

32 Sobre las irregularidades del estilo de Clemente: A. Mehat, Étude sur les Stromates de Clément d'Alexandrie (París 1966) 235-239; VÖLKER [n 24] 207-219.

33 Utilizo la edición de O. STÄHLIN de 1909 en su revisión por L. FrÜChTL-U. Treu, GCS 17 (Clem 3) (Berlín 1970). Para la interpretación de varios pasajes obscuros he tenido en cuenta las traducciones de O. STÄHLIN, Des Klemens von Alexandreia «Der Erziher II-III» und «Welcher Reiche wird gerettet werden?» (BKV [2 Reihe] 8 [Munich 1934]) y de G.W. Butterworth, Clement of Alexandrie, The Exhortation of the Greeks and the Richman's Salvation (Londres $191=1990)$ [col Loeb]. 


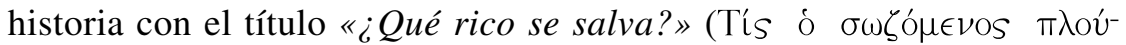
olos; en latín Quis dives salvetur?; en lo sucesivo Div.). Se ha discutido si la obra es una homilía destinada a la predicación o un tratado formativo orientado a la lectura (Stählin Rither). Su extensión es reducida (32 páginas en la edición de Stählin). Su tradición manuscrita es deficiente, ya que para la mayor parte del opúsculo se conservan sólo dos manuscritos: el de El Escorial ( $\Omega$ III. 19), del siglo XI o XII; y el de Roma (Vat. gr. 623), que es copia del anterior. El tema del opúsculo es la posibilidad de salvación de los ricos. Por lo que aparece al principio (Div 2.1-3), trataba de salir al paso de la inquietud que suscritaba el problema entre los destinatarios. Dada la escasez de datos biográficos sobre Clemente es imposible determinar la fecha y el lugar (¿Alejandría?, ¿alguna ciudad de Capadocia?) en que escribió el opúsculo ${ }^{34}$.

Desde el punto de vista de su estructura la obra consta de los elementos que se exponen a continuación, debiendo tenerse en cuenta que la sistemática seguida por Clemente no es rígida y que con frecuencia se entremezclan los temas.

a) Introducción (Div 1-3).

b) Primera parte o principal, en la que sobre la base de la perícopa del Evangelio de Marcos (Mc 10, 17-31) expone sus ideas sobre la compatibilidad de la riqueza con la salvación y su concepto de pobreza y riqueza espiritual (Div 4-28). En esta parte se explica además el sentido de diversos pasajes evangélicos relacionados con el tema.

c) Segunda parte (íntimamente relacionada con la anterior), en la que expone el deber de caridad y beneficencia del verdadero rico (de acuerdo con diversos pasajes de la Escritura (Div 28-36).

d) Tercera parte, en la que Clemente realiza un elevado encomio de la caridad y de la penitencia (Div 37-41).

e) Apéndice, que contiene como confirmación la leyenda del discípulo de Juan, que se hizo jefe de bandoleros pero acabó salvándose mediante la penitencia (Div 42, 1-19), casi enteramente transcrito en Eus, HE 3, 23, 6-19).

f) Doxología final (Div 42, 20).

El hecho de que en la obra de Clemente la exégesis de la perícopa de Mc sea un elemento básico, hace que no se pueda esperar una argumentación sistemáticamente perfecta. Naturalmente la consecución de

34 Sobre algunas características gramaticales de la obra: J. FANTINI, «Sintaxis participial en el tratado Quis dives salvetur de Clemente de Alejandría»: Helmántica 1 (1950) 572-573, 606-607. 
ideas en un texto evangélico dista mucho de la de un tratado filosófico, sobre todo teniendo en cuenta la estructura del pasaje comentado que examinaremos más adelante $(\S 4)$. Además hay que tener en cuenta que la exposición de Clemente no sigue un orden estrictamente sistemático ni el de un comentario temático. A ello hay que añadir que en toda la producción literaria de Clemente ni el estricto orden sistemático de la exposición ni el rigor terminológico son rasgos dominantes. Como resultado de estos factores ocurre que en Div se repiten inevitablemente las mismas ideas a veces con diversos matices y con términos no siempre rigurosamente técnicos. Por ello, parece preferible no seguir en este trabajo el orden exacto de la exposición de Clemente, sino agrupar sus ideas sistemáticamente y completarlas o aclararlas con las que sobre el mismo tema aparecen dispersos en sus obras. Los temas fundamentales elegidos para agrupar las ideas de Clemente son tres: la indiferencia ética de la riqueza $(\S 3)$, su concepto ético-espiritual de riqueza y pobreza $(\S 4)$ y la función de la beneficencia en ese concepto $(\S 5)$.

\section{La indiferencia de la riqueza}

Tras una especie de exordio en el que dice que no hay que adular a los ricos, lo que contribuiría a que su salvación fuera todavía más difícil, y que lo que se ha de hacer es ayudarles (Div 1, 1-5), Clemente expone claramente el problema: hay ricos que ante las palabras del Evangelio de que es más fácil el paso de un camello por el ojo de una aguja que la salvación de un rico (Mc 10, 15 par), desesperan de toda posibilidad de salvarse, sin detenerse a indagar el verdadero sentido de estas palabras, mientras que otros que conocen su sentido verdadero no actúan en consecuencia (Div 2, 2-3). A ambos grupos hay que ayudar ante todo haciéndoles perder el miedo infundado de no poder obtener la salvación eterna (Div 3,2). Para ello expone en primer lugar que la riqueza en sí misma no es mala, sino indiferente, y aduce una serie de argumentos filosóficos y teológicos.

Desde un punto de vista racional fenomenológico, Clemente afirma que la carencia de bienes temporales es irrelevante en el campo éticoreligioso: no hace a los que la padecen ni más felices, ni más queridos de Dios, ni poseedores de la vida eterna (Div 11,3). Más aún, quien se encuentra en situación de extrema pobreza se halla polarizado por la preocupación de salir de ella por cualquier medio (Div 12, 4). En otros pasajes añade que los pobres pueden ser viciosos y los ricos virtuosos (Div 18,5$)$ y que el que carece de bienes materiales puede ser rico en pasiones, porque la constitución de la naturaleza humana lleva a que en 
esas circunstancias se ahogue el razonamiento y se inflamen las apetencias congénitas, de forma que nada aproveche el ser pobre en riquezas pero rico en pasiones, porque no se ha desprendido uno de lo que hay que desprenderse, sino de lo indiferente, y por un lado ha cercenado lo que estaba a su servicio y por otro ha dado fuego a la leña de maldad inherente a la carencia de bienes externos (Div 15, 2-3). En otro pasaje pone también de relieve su escepticismo respecto al valor ético-religioso de la carencia de bienes materiales:

Div 11, 3 (GCS 17, 166-167).

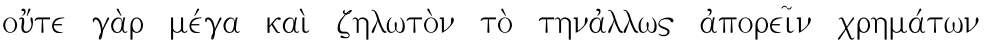

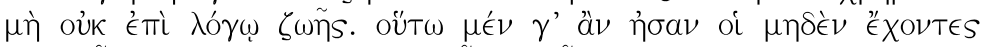

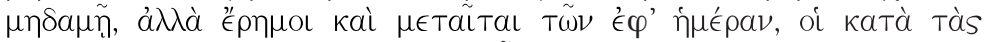

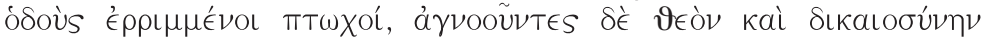

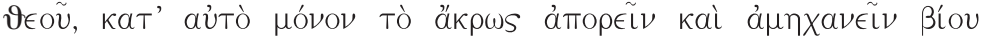

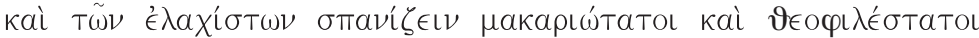

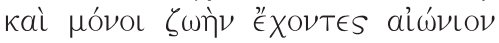

Nada tiene de grande ni de deseable el carecer simplemente de bienes materiales, incluso de los necesarios para subsistir: en tal caso los que carecen totalmente de todo, los solitarios que mendigan lo necesario para cada día, los pobres arrojados por los caminos, desconocedores de Dios y de la justicia de Dios, por el solo hecho de carecer enteramente de todo y de su desesperanza de la vida y de estar privados de las menores cosas, serían los más bienaventurados y los más amados de Dios y los únicos que obtendrían la vida eterna.

En comparación con los numerosos pasajes del Antiguo Testamento (sobre todo Profetas y Salmos) en que aparece la crítica social de la riqueza y la antes mencionada mística de la pobreza, o en comparación también con los muchos textos de los Evangelios sinópticos que reflejan una fuerte sensibilidad de Jesús ante la situación de los pobres, llama la atención la relativa frialdad con que Clemente (como más tarde Orígenes) alude a la situación de los económicamente pobres y socialmente descalificados ${ }^{35}$.

En una prolepsis retórica Clemente se adelanta a responder a la previsible objeción de que famosos filósofos, entre los que menciona a

35 Orig, Cels 6, 16 (SC 147, 618. Apunta también esta falta de sensibilidad: H.V. CAMPENHAUSEN «Die Askese im Urchristentum» en: IDEM, Tradition und Leben (Tubinga 1960) 128-129. Una crítica parecida a la realizada por Clemente (pero más dura y agravada con otros matices) aparecerá más tarde en Porfirio, que considera absurda la preferencia de los pobres en orden a la salvación, e indica que tal vez esas ideas en el Evangelio no procedan de Jesús sino de embaucadores que pretendían así adueñarse de los bienes de los ricos incautos (Porph, Christ frg 58 [ed A.v. HARNACK, AbhAkBerl 1916/1, 89-83]). 
Anaxágoras, Demócrito y Crates, se habían desprendido de sus bienes para donarlos a sus ciudades o repartirlos entre los pobres: apunta que en ese desprendimiento hubo un motivo de ostentación y vanagloria desprovisto de valor ético (Div 11, 4; 12, 2). Clemente considera que es mucho mejor tener lo suficiente para vivir y poderse ocupar de cosas más importantes que la subsistencia (Div 13,1). Para la mentalidad actual resulta llamativa la facilidad con que Clemente atribuye fines bastardos al desprendimiento de algunos filósofos. Sin embargo, esta dureza está plenamente de acuerdo con las reglas usuales de la fi-

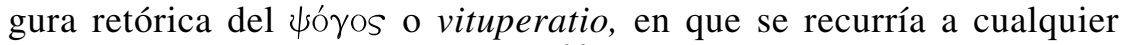
medio para denigrar al adversario ${ }^{36}$. Llama también la atención que Clemente en este contexto no haga la menor referencia a la comunidad de bienes que probablemente se dio en algunos grupos cristianos de los primeros tiempos, y a la existencia probablemente todavía en su época de maestros carismáticos itinerantes con carencia de bienes pro$\operatorname{pios}^{37}$.

Desde el punto de vista de la dinámica social Clemente aduce la

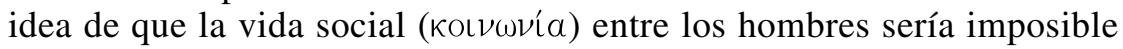
si todos careciesen de bienes (Div 13, 1). Más tarde esa misma idea sería desarrollada retóricamente en un tono de dura crítica irónica por el emperador Juliano (361-363) en su obra Contra los galileos escrita poco antes de su muerte ${ }^{38}$.

A lo largo de todo su opúsculo sobre la riqueza utiliza Clemente una serie de conceptos filosóficos típicos de la ética estoica, que había hecho también suyos el platonismo medio de la época imperial ${ }^{39}$. El más importante de esos conceptos es el de la indiferencia moral de determinadas cosas, ya que de acuerdo con la ética estoica hay cosas que son naturalmente buenas y otras naturalmente malas: bueno es lo que conduce al hombre a su último fin o ayuda a alcanzarlo, y malo, lo contrario. Al lado de tales cosas hay muchas que en sí pertenecen al grupo

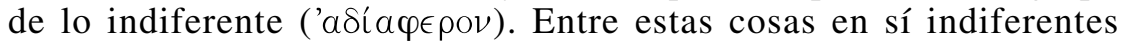
mencionan los estoicos la salud, la belleza corporal, la riqueza, etc. $\mathrm{Su}$

36 Sobre esta figura retórica empleada con frecuencia en la retórica cristiana: R. VoLKMANN, Die Rhetorik der Griechen und Römer in systematischer Übersicht ${ }^{2}$ (Leipzig $1885=$ Darmstadt 1983) 321-330; J. MARTIN, Antike Rhetorik (Munich 1974) 188-203.

${ }^{37}$ Act 4, 32-37, 5, 1-11; Did 11,4-6; 12, 1-13, 2. Sobre estos pasajes ver: A. AudET, La Didaché (París 1958) 435-447, 453-457; KreTsChMAR, Beitrag [n 10] 135-156; B. LoHSE, Askese und Mönchtum in der Antike und in der alten Kirche (Munich-Viena 1969) 173-177.

38 Jul, Gal frg 5 (ed W.C. WRIGHT [Londres-Cambrige Mass 1913-1923] 3, 430-431) reproducido también en: K.J. NeumanN, Iuliani imperatoris librorum contra Christianos qui supersunt (Leipzig 1880) 237.

39 Sobre el eclecticismo de Clemente ver: n. 25. 
valor o utilidad ética depende del uso que de ellas haga el hombre por decisión interna y libre, en orden a obtener su perfección moral ${ }^{40}$. En contraposición a esa decisión personal interna, esas cosas indiferentes son externas al alma, con lo que se establece una contraposición entre las cosas internas ( $T \grave{d}$ ÉVTós) y las externas (Tò éKTós) que aparece constantemente en el opúsculo de Clemente ${ }^{41}$. Las cosas externas indi-

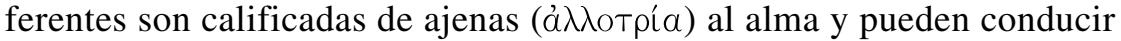
a la alienación caso de que el hombre se deje arrastrar por ellas ${ }^{42}$. Concepto fundamental en la ética estoica y en la de Clemente es el de las pasiones ( $\pi \alpha ́ \theta \eta)$ concebidas como inclinaciones no procedentes de la

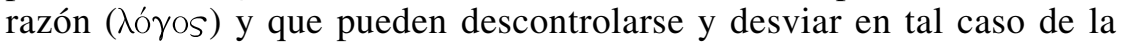
consecución de la perfección ética ${ }^{43}$.

Dentro de ese marco de la ética estoica Clemente presenta la riqueza como algo éticamente indiferente. Los bienes son cosas dadas por

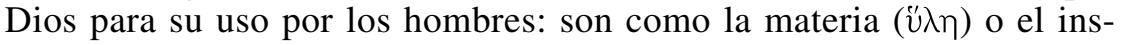
trumento (öpravov) para hacer buen uso de ellos (Div 14, 1). El instrumento si se usa bien es útil; pero si se usa mal, no es culpable de ese mal uso (Div 14, 2). La riqueza es un instrumento de ese tipo, que puede ser usado justa o injustamente con efectos totalmente contrapuestos (Div 14, 3). La riqueza por tanto no es en sí misma ni buena ni mala, y el resultado bueno o malo de su empleo depende de la mente (voũs),

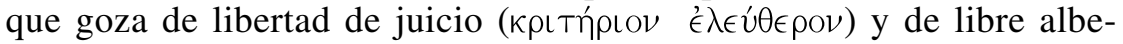

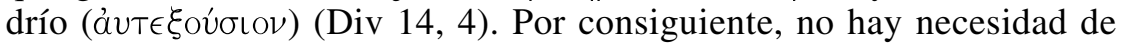
desprenderse de la riqueza, sino de eliminar las pasiones que llevan a su mal uso (Div 14, 5) ${ }^{44}$. Para dejar aún más claro lo dicho, Clemente insiste en que es posible que quien se haya desprendido de sus bienes siga siendo rico en pasiones por haber eliminado, no aquello de lo que hay que desprenderse ( $\tau \grave{\alpha}$ àmó $\beta \lambda \eta T \alpha$ ), sino lo indiferente (Div 15, 2). Clemente insiste en que la salvación no consiste en lo externo (que es indiferente) sino en la virtud del alma (Div 18, 1); en que las cosas exteriores no hacen daño, y por lo tanto de lo que hay que desprenderse

40 Sobre el concepto estoico de idiferencia ética: SVF 3, 117-168; E. SchwARTZ, «Zu

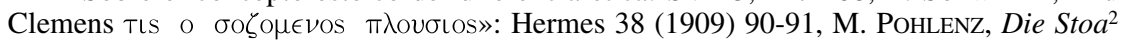
(Gotinga 1959) 1, 119-123; RITTER [n 25] ZKG 86 (1975) 10-11.

41 Sobre los conceptos de lo interior y lo exterior en la ética estoica: SVF 3, 96-97; 136; 153; 764. Sobre el concepto: A. DyrofF, Die Ethik der alten Stoa (Berlín 1987) 40.

42 Para el sentido de $a \lambda \lambda$ ot $\rho$ ov en la ética estoica: SVF 3, 178. Para el ulterior desarrollo: RitTER [n 25] ZKG 86 (1975 10 n 39 (en Séneca); G.W.H. LAMPE, A Patristic Greek Lexicon (Oxford $1961=1991) 77$ (en los escritores cristianos).

43 Sobre el concepto de pasión ( $\pi \alpha \theta 0 s$ ) en la ética estoica: SVF 3, 377.378.384.462.476; PoHLENZ, Stoa ${ }^{2}$ [n 40] 1, 141-143; LiLla [n 25] 84-92; VöLKER [n 24] 183-188; 524-546.

44 Sobre el concepto de libertad en Clemente: VöLKER [n 24] 115-120. 
es de lo que causa mal al alma, no de los instrumentos que pueden ser empleados para hacer el bien (Div 15, 4-6). En un importante pasaje dice textualmente:

Div 15, 6-16, 1 (CGS 17, 169)

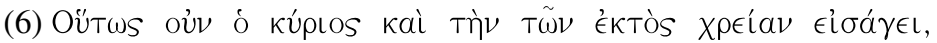

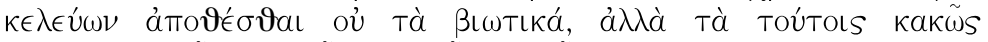

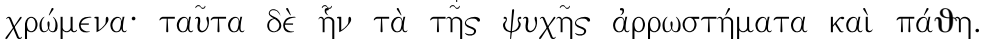

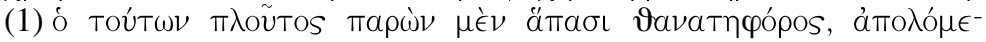

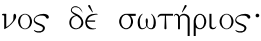

(6) Así el Señor admite el empleo de las cosas exteriores, mandando desprenderse no de los bienes temporales, sino de las cosas que hacen que se usen mal (aquellos). Estas cosas son las debilidades del alma y las pasiones. (1) La abundancia en estas (últimas) cosas es mortífera para todos, y su destrucción, salvadora.

Desde el punto de vista de la teología natural, Clemente afirma que no hay nada malo en que uno antes de su conversión al cristianismo se haya enriquecido por su trabajo y ahorro, y que todavía es menos reprobable que uno haya nacido en una familia acomodada (Div 26, 3). Para reforzar esta idea pone de relieve que Dios es quien distribuye la

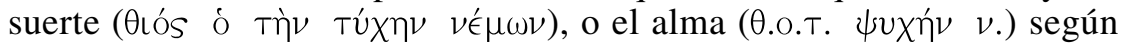
otra posible lectura, y que sería injusto que excluyese a alguien de la vida eterna por haberle hecho nacer en una familia rica (Div 26, 4) ${ }^{45}$. Añade que sería absurdo que existiesen riquezas en la tierra si llevasen necesariamente a la perdición (Div 26, 5). Es curioso que Clemente no hace referencia en este contexto al enriquecimiento por medios lícitos de un cristiano después de su conversión. Naturalmente, de su silencio no cabe deducir que lo considerase reprobable.

En otro sector de su obra, Clemente argumenta con razones basadas directamente en el Evangelio. Afirma, en primer lugar, que quien carece de bienes temporales no puede cumplir los mandatos dados por el Señor de ayudar materialmente al prójimo y utilizar sabiamente las riquezas para obtener la vida eterna. Tras aducir numerosos pasajes evangélicos en este sentido (Lc 16, 9; Mt 6, 20; 25, 34-36) concluye que habría una total falta de lógica al mandar al mismo tiempo desprenderse de todos los bienes y hacer obras de misericordia (Div 13,

45 Clemente escribió una obra actualmente perdida sobre la providencia (ALTANERSTUiBer [n 19] 194). En Strom 5, 6, 1-3 (GCS 52 [Clem 2] 329) presenta el concepto de providencia como algo totalmente evidente de lo que no cabe dudar. Sobre el desarrollo

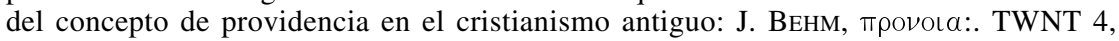
1.007-1.011. 
2-4; 6-7). La argumentación de Clemente no tiene en cuenta que una plena renuncia inicial mantenida a lo largo de la vida al servicio de los pobres, como aparece en el grupo que siguió a Jesús, es en sí misma una obra de misericordia continuada. Dentro del marco de argumentación con base en pasajes evangélicos, Clemente hace notar que entre los seguidores de Jesús hubo personas como Mateo y Zaqueo (Mt 9. 9-12; Lc 5, 27-29; 19, 1-10) a las que no mandó desprenderse de sus bienes (Div 13,5). Además señala que el Señor previó que algunos de sus seguidores perderían sus bienes en las futuras persecuciones (Mc 10, 30 par) y por consiguiente preveía sin censurarlo que habría personas que no habían tenido que dejar sus bienes para seguirle (Div 25, 1-2).

Todas estas consideraciones llevan a Clemente a la conclusión de que no hay necesidad de desprenderse de los bienes materiales como si fueran impedimentos excluyentes de la salvación (Div 27, 2). Por ello los ricos no han de desesperar de la posibilidad de salvarse (Div 26, 2; $38,4)$, sino que deben aprender cómo han de usar bien de las riquezas para obtener la vida eterna (Div 27, 1). Para Clemente el desprendimiento de que habla el Evangelio no se refiere a las riquezas materiales sino a las pasiones del alma (Div 14, 6). Al terminar una de las principales secciones en que trata directamente este punto, Clemente dice textualmente:

Div 26, 2 (GCS 17, 177)

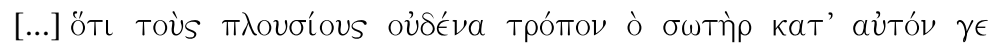

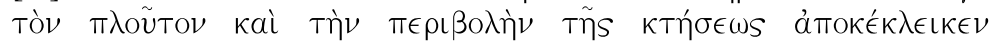

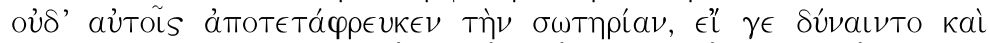

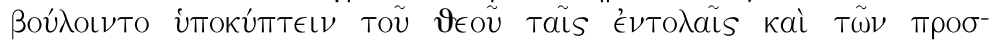

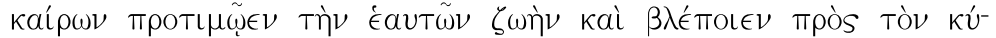

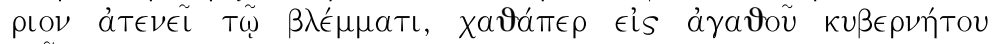
$\nu \in \tilde{U} \mu \alpha$

[...] El Salvador no excluyó en modo alguno a los ricos por razón de la riqueza en sí misma y de la abundancia de sus bienes, ni les cerró el camino de la salvación, con tal de que pudieran y quisieran someterse a los mandamientos de Dios, estimaran su vida (eterna) en más que las cosas temporales y pusieran su mirada atentamente en el Señor como en un buen piloto.

Esta concepción de la riqueza como algo éticamente indiferente que no tiene por qué ser abandonado para seguir a Cristo, no tiene en cuenta algunas de las concepciones de la pobreza que antes hemos visto y que se hallan presentes en el Evangelio. 


\section{La espiritualización del concepto de pobreza}

A fin de entender y valorar debidamente la interpretación que hace Clemente del texto evangélico que le sirve de base, voy a examinar brevemente la estructura y contenido del texto evangélico y los principios exegéticos de Clemente, para tratar luego con más detención de los puntos principales de su interpretación.

\section{a) El pasaje evangélico comentado (Mc 10, 17-31)}

Clemente reproduce en toda su extensión la perícopa del Evangelio que toma como base y hace notar expresamente que la toma del Evangelio de Marcos, y que aparece también en los otros Evangelios con ligeras variantes que no afectan al contenido (Div 5, 1). Efectivamente el pasaje en cuestión aparece en Mc 10, 17-31; Mt 19, 16-30; y Lc 18, 18-3046. Aparece también con algunas variantes en uno de los pocos fragmentos conservados (en este caso en traducción latina) del Evangelio de los Nazareos, que básicamente depende del de Mateo, pero que en este caso recoge tal vez una tradición independiente de él ${ }^{47}$. Sin embargo ninguna de estas variantes se refleja en el texto de Clemente. Reproduzco a continuación el texto evangélico tal como lo presentó Clemente, indicando en la traducción las principales variaciones respecto al texto de Marcos. Señalo también en la traducción (con letras mayúsculas) las cuatro unidades por las que probablemente está constituida la perícopa. Las cifras en cursiva corresponden a los apartados de Div y las cifras en redonda a los versículos de Mc.

Div 4, 4-10 (GCS 162-163) par Mc 10, 17-31

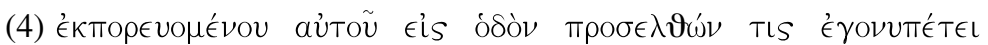
$\lambda \epsilon \epsilon \omega \nu$.

46 Para la adecuada valoración de la forma en que de hecho reproduce Clemente el texto evangélico, resulta sumamente útil el examen simultáneo del texto de los tres Sinópticos. Ver por ejemplo: K. ALAND, Synopsis quattuor Evangeliorum ${ }^{13}$ (Stuttgart 1985) nr 254-255 (pg. 238-243).

47 EvNaz 16 (en: Orig, CommMt 15, 14 [GCS 40 (= Orig 10) 389-390]). Texto traducido al alemán de todos los fragmentos conservados en: NTApkr 16, 133-138. EvNaz, del que se conservan solamente 36 fragmentos, fue compuesto probablemente en la primera mitad del siglo II en Siria sin que pueda saberse con seguridad si su original fue arameo o griego. En todo caso el pasaje que nos interesa, deriva muy probablemente de Mt al que modifica ligeramente y añade algunos detalles descriptivos. Sobre el tema: J. JEREMIAS, Unbekannte Jesusworte $^{2}$ (Gütersloh 1893) 47-50; A.F.J. KLIJN, «The Question of the Rich Young Man in a Jewish-Christian Gospel» NovTest 8 (1966) 149-165; P. VIELHAUER-G. STRECKER, «Judenchristliche Evangelien» en: NTApkr 16, 128-133. 


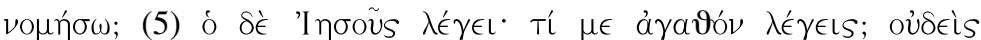

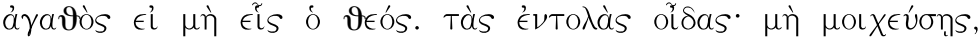

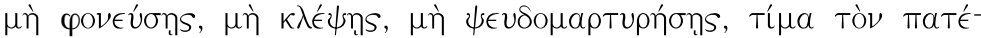

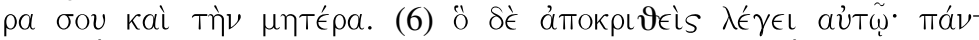

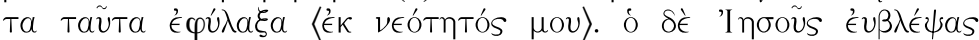

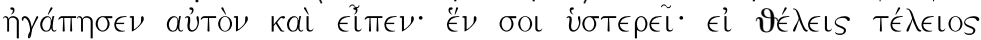

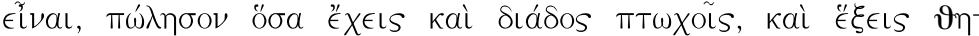

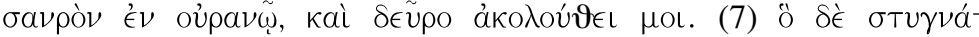

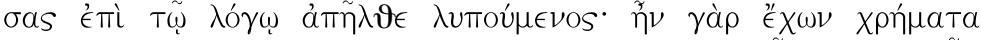

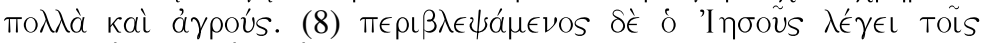

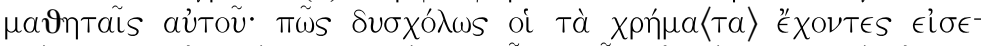

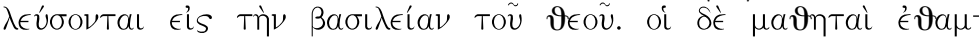

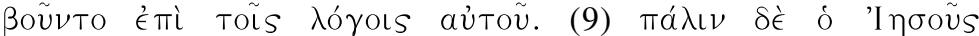

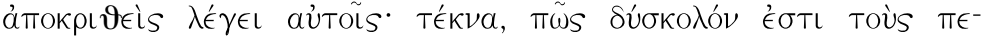

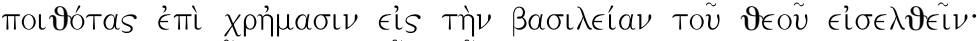

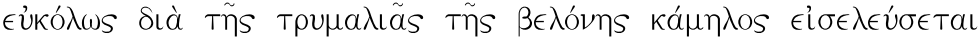

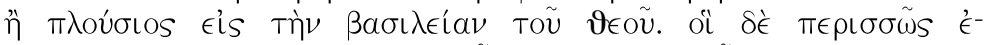

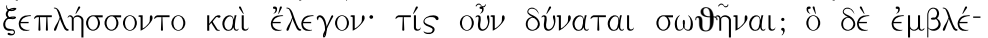

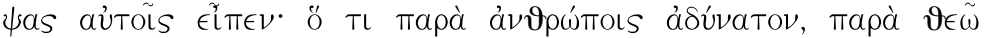

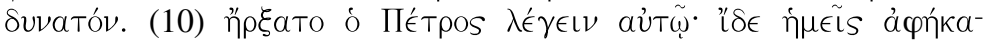

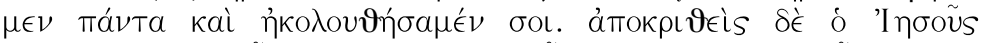

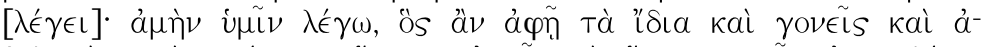

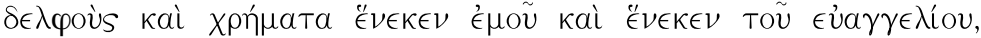

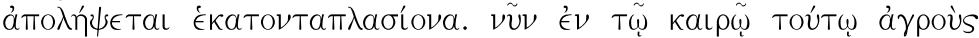

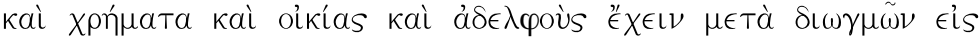

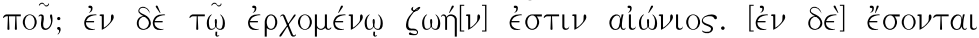

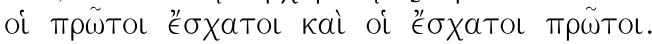

A (4) (17) Y al ponerse él (Jesús) de camino, uno viniendo (Mc corriendo) hacia él se arrodilló diciendo: (Mc arrodillado se preguntaba): «Maestro bueno; ¿qué debo hacer para conseguir la vida eterna?». (5) (18) Jesús le dice (Mc dijo): «¿Por qué me llamas bueno? Nadie es bueno sino sólo Dios. (19) Conoces los mandamientos: no adulteres, no mates, no robes, no des falso testimonio, honra a tu padre y a tu madre». (6) Él le respondió: «Maestro, todo esto lo he guardado» (Mc desde mi juventud). (21) Y Jesús, fijando en él la mirada, le amó y le dijo: «Una cosa te falta: si quieres ser perfecto (-Mc), vende todo lo que tienes y dalo a los pobres y tendrás un tesoro en el cielo y ven sígueme». (7) (22) Pero él, desolado por lo dicho, se marchó con pena, porque poseía muchos bienes y tierras.

B (8) (24) Y habiendo echado una mirada en torno, Jesús dice a sus discípulos: «iQué difícilmente entrarán en el Reino de Dios los que tienen bienes!» (Mc ¡Qué difícil es entrar en el Reino de Dios!). (24) Los discípulos se asombraban de sus palabras. (9) Jesús en respuesta les dice de nuevo: «Hijos, qué difícil es que los que han confiado en las riquezas (Mc-) entren en el Reino de Dios. (25) Más fácilmente entrará 
(Mc es más fácil que pase) un camello por el ojo de una aguja que un rico (Mc entre) en el Reino de Dios». (26) Y ellos se asombraban aún más y decían (Mc diciéndose entre sí): «Entonces ¿quién puede salvarse?». (27) Jesús, mirándoles, dijo (Mc dice): «(Lo) imposible entre los hombres es posible (Mc pero no) para Dios (Mc para Dios todas las cosas son posibles).

C (10) (28) Pedro empezó a decirle: «Mira, nosotros hemos dejado todas las cosas y te hemos seguido» (29) Jesús dice: «En verdad os digo:

el que deje lo suyo y padres y hermanos y riquezas por mi causa y por causa del evangelio, recibirá a cambio el céntuplo: ahora en este siglo tener tierras y riquezas y casas y hermanos entre persecuciones ihasta cuándo? pero en el (siglo) venidero está la vida eterna.

D Los primeros serán los últimos y los últimos primeros.
No hay nadie que haya dejado casa o hermanos o hermanas o madre o padre o hijos o tierras por mi causa y por causa del evangelio, (30) que no reciba ahora en este siglo (cien veces más) casas, y hermanas y madres, e hijos y [y hermanos tierras entre persecuciones, y en el siglo venidero de vida eterna. (31) Muchos primeros serán últimos, y últimos primeros.

Como se ve, en la transcripción de Clemente aparecen numerosas divergencias respecto al texto establecido en la edición crítica de Nestle-Aland: unas son simples omisiones de alguna palabra o susti-

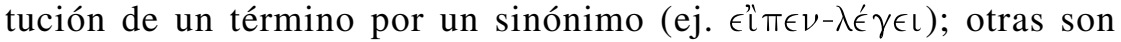
simples cambios de orden de las mismas palabras; otras son claras contaminaciones con los textos de Mateo y Lucas ${ }^{48}$. Todo ello es perfectamente explicable en una persona que escribe o dicta deprisa, está muy familiarizada con el texto de los tres Sinópticos y no pone excesivo interés en la exactitud, consciente (como estaba Clemente) de que las diferencias entre los Sinópticos eran irrelevantes para el tema tratado (Div 5, 1).

Como era usual en la exégesis bíblica de su época, Clemente presenta toda la perícopa como un bloque con unidad histórica, aunque probablemente el pasaje en su origen fuera producto de la yuxtaposición (con sutura no plenamente lograda desde el punto de vista estilístico) de

48 Examen de las variaciones de Clemente respecto del texto de Mc en: Schwartz [n 40] Hermes 38 (1903) 87-90. M. Sмiтн, Clement of Alexandria and a Secret Gospel of Mark (Cambridge Mass 1973) 368-369 presenta un cuidadoso cuadro de estas divergencias textuales, que sin embrago no son válidas como argumento sólido para la tesis que Smith construye en su obra. 
cuatro unidades que debieron de ser independientes en la primitiva tradición y que fueron secundariamente unidas por el redactor del Evangelio de $\operatorname{Marcos}^{49}$. Como se hace notar en la precedente traducción, esas unidades son las siguientes:

A) Episodio del joven rico (Div 4, 1-7 = Mc 10, 17-22).

$B$ ) Diálogo entre Jesús y los discípulos sobre la dificultad de la salvación de los ricos (Div 4, 890 Mc 10, 23-27).

C) Respuesta de Jesús a Pedro sobre lo que debían esperar los que lo han dejado todo por seguirle (Div 4, $10 \mathrm{a}=\mathrm{Mc} 10,28-30$ ).

D) Dicho de Jesús sobre la subversión de valores (los últimos y los primeros), débilmente vinculado con lo anterior (Div 4, $10 \mathrm{~b}=\mathrm{Mc} 10,31$ ).

El primero de esos elementos (A) describe una típica llamada de Jesús a su seguimiento con la exigencia de dejarlo todo e ir tras él ${ }^{50}$. No cabe entrar aquí en la discusión del valor histórico del marco circunstancial en que se encuadra en este caso el llamamiento. Sí interesa en cambio resaltar que la invitación a dejarlo todo y seguirle coincide sustancialmente con otros mandamientos recogidos en los Evangelios (Mt 8, 19; 8, 22; Mc 2, 14 par; 8, 34 par; Lc 5, 10-11; 9, 61-62). Se trata de la invitación a formar parte del grupo de seguidores que en adelante deberán entregarse por entero al anuncio del Reino de Dios y compartir su vida dentro del marco escatológico de su predicación en Galilea. Es una llamada en unas circunstancias posteriormente irrepetibles en las que se invita al seguimiento incondicional de Jesús con su gran ascendiente personal, en un ambiente y unas circunstancias en las que el valor de las cosas temporales queda relativizado por la proximidad del fin y los bienes resultan un estorbo para dedicarse plenamente a la misión. Además esa misión se dirige predominantemente al pueblo llano pobre y oprimido, anuncia con firmeza el triunfo escatológico de la justicia sobre los opresores y encuentra su mayor oposición en los sectores sociales altos bien establecidos. Ese marco es muy distinto de la llamada a la perfección siguiendo a Cristo en la época y el ambiente

49 Sobre la perícona de Mc: N. WALTER, «Zur Analyse von Mk 10, 17-31»: ZNW 53 (1962) 206-217; K.G. REPLOH, Markus Lehrer der Gemeinde: eine redaktionsgeschichtliche Studie zu der Jungerperikope des Markusevangeliums (Stuttgart 1969) 191-201; W. HARNISCH, «Die Berufung des Reichen: Zur Analyse von Mk 10, 17-27, en: FsFuchs (Tübingen 1973) 162-166; W. SchmithaLs, Das Evangelium nach Markus ${ }^{2}$ (Gutersloh-Würzburg 1986) 2, 452-460.

50 Sobre el sentido y contenido histórico de la llamada de Jesús a su seguimiento:

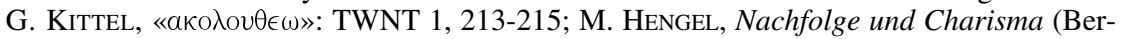
lín 1968) 63-82; E. LoHSE, «Nachfolge Christi»: RGG 3 4, 1.286-1.287. 
de Clemente ${ }^{51}$. Es significativo que entre las adiciones de Clemente al texto del Evangelio de Marcos se encuentra la adición del Evangelio de Mateo en la que a la invitación de dejarlo todo, precede la especificación condicional «si quieres ser perfecto», con lo que la renuncia a los bienes parece preentarse con carácter de supererogación.

La segunda mitad (B) pone de relieve la dificultad de la salvación de los ricos y consta de tres elementos no perfectamente unidos entre sí: (a) Afirmación de Jesús en forma gramatical exclamativa ( $\pi \tilde{\omega} s)$ en que se pondera la dificultad de que los ricos entren en el Reino (Mc 10, 23 = Div 4, 8). (b) Nueva afirmación de Jesús también en forma exclamativa sobre la dificultad de la salvación en general, en respuesta a la reacción de asombro que entre los discípulos había producido el elemento anterior. Una de las divergencias de Clemente respecto al texto de los principales manuscritos del Evangelio de Marcos es que Clemente (con otros importantes manuscritos) circunscribe también aquí la dificultad de la salvación para los que han confiado en sus bienes (oi

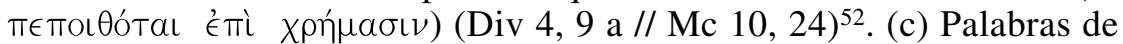
Jesús que confirman y ponen de relieve la dificultad señalada en el elemento anterior. Es la conocida máxima del camello y la aguja (Div 4, $9 \mathrm{~b}=\mathrm{Mc} 10,25)$ que expresa la dificultad de la salvación de los ricos ${ }^{53}$. El camello es el animal más grande conocido en Palestina y el orificio de la aguja, el paso más pequeño: se trataba de expresar la extrema dificultad y se hacía de la forma hiperbólica y paradójica que aparece en bastantes otros casos en la predicación de Jesús, por ejemplo: los fariseos al ir a beber cuelan los mosquitos y se tragan los camellos (Mt 23, 24), los hipócritas se fijan en la brizna que se ha metido en el ojo ajeno, y no advierten la viga que llevan en el suyo (Mt 7, 3-5) ${ }^{54}$. Los ejemplos

51 Sobre el concepto de seguimiento de Cristo hacia la perfección en el marco histórico posterior: KRETSCHMAR, Beitrag [n 11] 161-167; K.S. FRANK, Askese und Mönchtum in der alten Kirche (Darmstadt 1975) 1-3; IDEM, Geschichte des christlichen Mönchtums ${ }^{4}$ (Darmstadt 1983) 1-15.

52 Varios manuscritos recogidos en el aparato crítico de NESTLE-AlAnd (NT26 123 app) y en AlAnd, Synopsis ${ }^{13}$ [n 46] 339 contienen esta adición. En el texto de Clemente se trata probablemente de un añadido realizado por el autor, sin que pueda precisarse si es una adición voluntaria o una consecuencia de que posiblemente Clemente citaba de memoria, y sin advertirlo mezclaba las formulaciones de Mc y Mt.

53 Sobre el probable sentido originario del dicho del camello y los tardíos intentos de suavizar su dureza: T. ZAHN, Das Evangelium nach Matthäus ${ }^{2}$ (Leipzig 1910) 598-599, n 71;

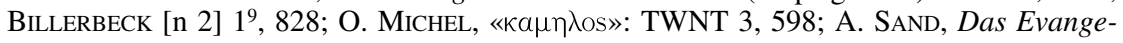
liun nach Matthäus (Regensburg 1986) 398.

54 Acerca de la hipórbole en los dichos de Jesús: R. Bultmann, Geschichte der synoptischen Tradition ${ }^{9}$ (Gotinga 1979) 180. 
podrían multiplicarse. El ambiente histórico del dicho de Jesús y su modo de hablar difieren muchísimo de los de Clemente. (d) El último elemento de la unidad (B) es una puntualización por parte de Jesús por medio de una nueva máxima (posibilidad para Dios de lo imposible para los hombres) para salir al paso de la zozobra de los discípulos (Div 4, 9c = Mc 10, 26-27). En toda esta unidad (B) se manifiesta claramente la prevención de Jesús frente a la riqueza como obstáculo muy difícilmente superable para entrar en el Reino.

La tercera unidad (C) presenta en los otros dos Sinópticos (Mt 19, 27-30; Lc 18, 28-30) bastantes diferencias de estructura y formulación respecto al Evangelio de Marcos (Mc 10, 28-30). A su vez el texto de Clemente (Div 9, 10a) se aparta notablemente de todos ellos ${ }^{55}$. Desde el punto de vista de este trabajo interesa señalar que el pasaje pone de relieve el tipo de seguimiento pleno (con dejación de todo lo terreno) que se daba en el grupo que seguía inmediatamente a Jesús, y el marco escatológico en que se concebía ese seguimiento. Aunque Clemente trata más adelante estos textos (Div 22, 1-23, 1) su contenido no afecta directamente al tema de este estudio.

Algo parecido ocurre con la cuarta unidad (D), donde se explicita (también en forma de máxima) la subversión de valores (últimos y primeros) en el Reino de Dios (Div 4, $10 \mathrm{~b} / / \mathrm{Mc} 10,31)^{56}$. Clemente sólo menciona este versículo de Marcos más tarde (Div 26, 1) indicando que el tema es complicado y no hay por qué tratarlo en esa ocasión.

\section{b) Principios exegéticos de Clemente}

Es sumamente interesante examinar cómo compaginó Clemente todos estos textos evangélicos claramente adversos a la riqueza con los principios que hemos visto que sostenía sobre su indiferencia ética.

Clemente concebía la Sagrada Escritura como palabra de Dios y por tanto como fuente primaria del verdadero conocimiento, y la considera como una unidad en la que todos los libros que la constituyen tienen igual autoridad ${ }^{57}$. Aunque en un pasaje de su obra indica que es conveniente tener en cuenta las peculiaridades de la lengua hebrea para entender bien ciertos pasajes (Strom 6, 129, 1 [GCS 15 (Clem 2) 497]), su método exegético, como el de casi todos sus contemporáneos,

55 Detalles en: Aland, Synopsis ${ }^{13}$ [n 46] 341-343.

56 Sobre el dicho acerca de los últimos y los primeros, que se repite en distintos contextos: Bultmann [n 54] 110; Schmithals, EvMk [n 49] 460.

57 Acerca de las ideas sobre la Escritura y la utilización que de ella hace Clemente: C. Mondésert, Clément d'Alexandrie (París 1944) 153-159. 
generalmente no tiene en cuenta la diversidad de los géneros literarios ni las circunstancias históricas y culturales que pudieron influir en la formulación del texto. En cambio, Clemente adapta a la interpretación de la Sagrada Escritura el sistema de alegorización desarrollado por los pensadores griegos desde el siglo IX a.C. para interpretar muchos mitos populares griegos, tratando de ver en ellos una verdad (cosmológica, ética, etc.) más profunda encubierta y figurada por el sentido literal de cada mito ${ }^{58}$. Los judíos alejandrinos, sobre todo Filón, habían aplicado este método a la exégesis del Antiguo Testamento y los cristianos de Alejandría lo habían hecho suyo ya antes de Clemente ${ }^{59}$. Este lo desarrolló con profusión distinguiendo entre un sentido literal y un sentido espiritual alegórico.

Como es frecuente en sus obras, Clemente emplea en este punto una terminología variable: al sentido literal lo caracteriza de carnal, humano, superficial, oscuro, rural, etc., mientras que al sentido alegórico lo presenta como místico, oculto, divino, superior, exacto, espiritual, etc. La interpretación alegórica no es para Clemente arbitraria sino que deriva del fondo teológico que la Escritura pretende siempre enseñar, al que se llega sólo por una profundización ilustrada por la fe y la $\gamma \nu \tilde{\omega} \sigma \iota s$, que va más allá del sentido literal y requiere un alto nivel de perfección en el interesado ${ }^{60}$. Por lo que se refiere a la perícopa que nos interesa, Clemente hace la siguiente observación previa:

Div 5, 2 (GCS 17, 163)

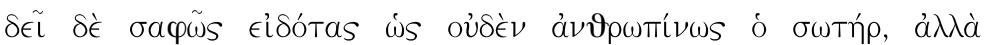

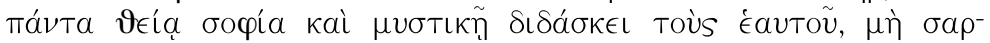

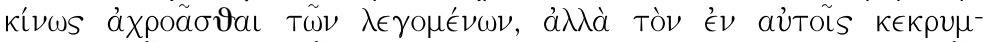

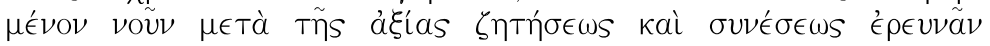

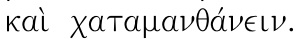

Es preciso que los que saben claramente que el Salvador no enseña nada a los suyos al modo (meramente) humano, sino todo con sabiduría divina y mística, no oigan carnalmente lo dicho, sino que indaguen y

58 Visión general del proceso de alegorización de los mitos en el mundo griego en P. WeIndLAND, Die hellenistische-römische Kultur in ihren Beziehungen zu Judentum und Cristentum (Tübingen 1912) 112-122; W. NESTLE, Griechische Geistesgeschichte (Stuttgart 1944) 95-98.

59 Sobre la interpretación alegórica del AT por Filón: C. COLPE, «Philo»; RGG ${ }^{3}$ 5, 344-345; E. DIETRICH, «Schriftauslegung»: $\mathrm{RGG}^{3}$ 5, 1.516 .

60 MondÉsert, Clément [n 57] 153-154, Völker [n 24] 395. La acentuada tendencia hacia la interpretación espiritual con preferencia sobre la literal llevó a veces a Clemente a excesos y aporías. Ver sobre este punto: A. JüLICHER, Die Gleichnisreden Jesu ${ }^{2}$ (Tubinga 1910 = Darmstadt 1976) 1, 220-221. 
capten el sentido escondido en ello con congruente examen y conocimiento íntimo.

A continuación puntualiza aún más algunos aspectos de ese sentido místico de la Escritura: dice que aun las cosas expuestas con claridad por Jesús a sus discípulos necesitan mucha atención por la abundancia de contenido que hay en ellas, aunque aparentemente sean sencillas; añade que siempre se refieren a cosas importantes pertinentes a la salvación e implican una admirable y celestial profundidad de pensamiento, por lo que no han de oírse con superficialidad sino dirigiendo la mente al espíritu mismo del Salvador y a lo indecible de la doctrina (Div 5, 3-4).

Con estas premisas Clemente emprende la interpretación espiritual de la perícopa del Evangelio de Marcos. No tiene en cuenta las circunstancias históricas del texto evangélico, muy distintas de las suyas, no recurre al examen del género literario y se centra en la interpretación alegórica.

\section{c) Interpretación espiritualista de Clemente}

El concepto de seguimiento a Cristo tuvo que ser cambiado por Clemente respecto al que aparece en los Sinópticos, donde, como hemos visto, aparecía con caracteres irrepetibles. En un pasaje sintetiza la esencia del seguimiento tal como él lo concibe:

Div 21, 7 (GCS 17, 174)

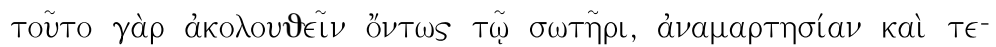

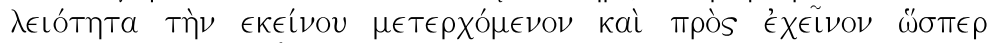

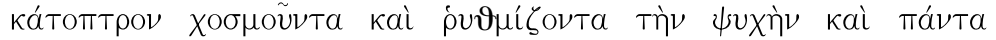

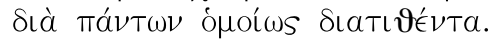

Esto es seguir realmente al Salvador: ir tras su impecabilidad y perfección, ordenar y adornar el alma tomándole como espejo, y acompasarla a él, y habiendo dispuesto todas las cosas de esta misma manera.

Esta descripción está en pleno acuerdo con su concepción de la per-

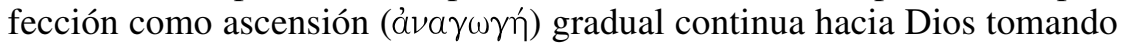
como modelo a Cristo. En muchos pasajes de sus obras aparece constantemente esta idea expresada con distintas comparaciones: en la segunda de sus tres obras mayores Cristo es el pedagogo en el sentido del logos divino que ilumina, forma y educa a la humanidad (Paed 1, 1-4) ${ }^{61}$; en el

61 La idea de Cristo como pedagogo fue ampliamente desarrollada por Clemente en su obra de este mismo nombre. Ver particularmente: Clem, Paed 1, 7, 53-61 y la introducción de H.I. MARROU, SC 70, 154-19. 
opúsculo sobre la riqueza presenta a Cristo como el preparador que adiestra al cristiano comparado con un atleta (Div 3, 3-6) ${ }^{62}$ o como el piloto de una nave a quien hay que atender constantemente (Div 26, 2$)^{63}$. En nuestro pasaje la comparación del espejo (que propiamente reflejaría la propia imagen, no la de Cristo) no es plenamente acertada. Lo es más la segunda, en que presenta a Cristo marcando el ritmo que se ha de seguir $^{64}$. Se trata siempre de un seguimiento por el perfeccionamiento continuo individual en el que el cristiano se esfuerza constantemente en seguir el modelo de Cristo. Como hemos visto ( $(3)$ ese seguimiento es presentado como compatible con la tenencia de los bienes materiales (Div 15, 6 reproducido en $\S 3$ ).

Además de en el pasaje comentado por Clemente (Mc 10,21) y en sus paralelos sinópticos (Mt 19, 21; Lc 18, 22), la recomendación de venderlo todo y dar su producto a los pobres aparece expresamente en un dicho de Jesús (Lc 12, 23) enclavado por el autor de Lc en una de las varias instrucciones a los discípulos (Lc 12,1-53) en el marco del viaje hacia Jerusalén ${ }^{65}$. El mismo autor en los Hechos de los Apóstoles presenta la venta de los bienes para ayuda de los pobres como práctica de la primitiva comunidad cristiana (Act 4, 32-37, 5, 1-11) ${ }^{66}$. En ambos casos se entiende como un acto de desprendimiento real-físico de los bienes propios y así ha sido entendido con diversas variantes en su realización práctica por distintas personas y grupos a lo largo de la historia del cristianismo ${ }^{67}$.

62 La comparación del cristiano con el atleta que ha de esforzarse para obtener el éxito, aparece ya en Pablo (1Cor 9, 24-26; Phil 3, 14; 2Tim 2, 5). Ver: E. STAufFER, «a $\theta \lambda \epsilon \omega »$; TWNT 1, 166-167. Clemente desarrolla de forma detallada el aspecto de Cristo como preparador de atletas a continuación del pasaje aquí comentado en su tratado sobre la riqueza (Div 3, 3-6).

${ }^{63}$ La idea de Cristo como piloto de nave aparece ya en las consideraciones finales del redactor o reelaborador anónimo del MartPolyc 19, 2 (AMA ${ }^{4}$ 7). Clemente desarrolla la idea en Paed 1, 54, 2-3. Sobre la concepción de la vida humana como una peligrosa travesía por mar, y su desarrollo por los escritores cristianos: H. RAHNER, Griechische Mythen in christlicher Deutung 3 (Darmstadt 1966) 291-328.

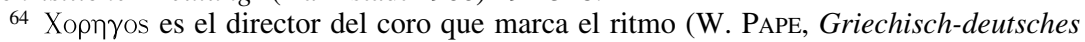
Handwörterbuch ${ }^{2}$ (Braunschweig 1874-1875) 1342). La idea de los dioses como directores de coro aparece ya en Plat, Leg 665a. Clemente la utiliza también en: Strom 5, 7, 8-5, 8, 1 (GCS 52 [Clem 2] 330).

65 Sobre este pasaje (Lc 12, 33) y su contexto: G. SCHNEIDER, Das Evangelium nach Lukas $^{2}$ (Gütersloh-Würzburg 1984) 2, 286-287; W.G. KüMME, Einleitung in das Neue Testament $^{21}$ (Heidelberg 1983) 110-111.

66 Ver $\mathrm{n} 10$.

67 Exposición de las grandes líneas del desarrollo del ideal de pobreza en el cristianismo en: L. HARDLICK, «Armut»: $\mathrm{RGG}^{3}$ 1, 624-627. 
Ante el pasaje del Evangelio en que Jesús indica al joven rico que venda sus bienes (Mc 10, 21), Clemente se ve forzado a dar una audaz interpretación alegórica del concepto de vender ${ }^{68}$. En ella pretende mostrar que vender $(\pi \omega \lambda \tilde{\epsilon} \nu)$ no ha de entenderse como cambiar cosas por dinero, sino como desprenderse del apego a los bienes temporales, cambiándolos por una riqueza espiritual consistente en el avance hacia la perfección. Lo explica en la siguiente paráfrasis de la recomendación de Jesús al joven.

\section{Div 19, 3-6 (GCS 17, 172).}

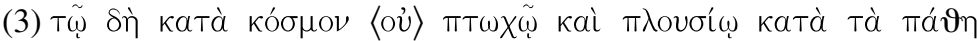

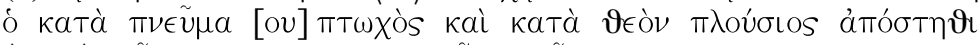

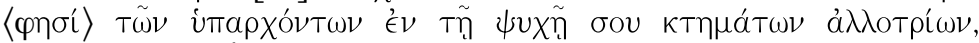

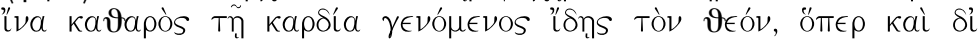

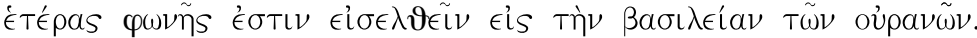

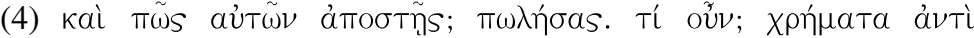

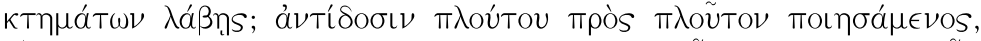

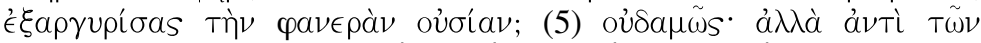

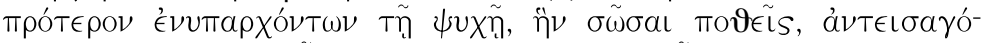

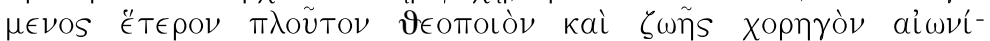

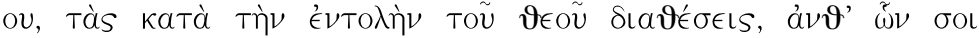

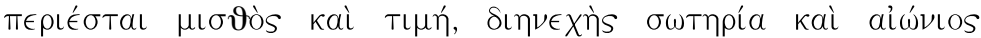

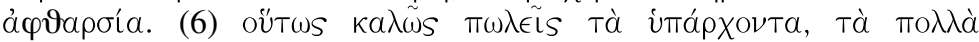

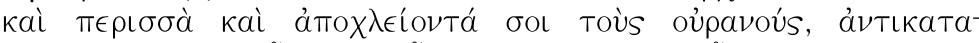

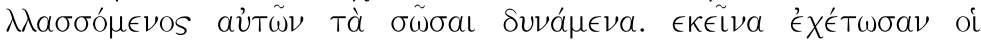

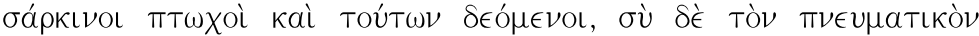

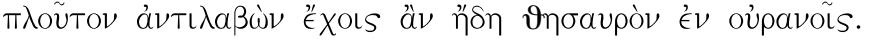

(3) $\mathrm{Al}\langle$ no $\rangle$ pobre según el mundo y rico en pasiones le dice el [no] ${ }^{69}$ pobre en espíritu y rico según Dios [= Jesús]: Sepárate de los bienes ajenos (a tu alma) que están en tu alma, para que al haberte hecho limpio de corazón, veas a Dios, lo que con otras palabras es entrar en el reino de los cielos. (4) Y ¿cómo te separarás de ellas? Vendiéndolas. ¿Pero qué? ¿tomarás bienes a cambio de bienes? ¿Acumularás el precio de los bienes a los bienes a liquidar el patrimonio visible? (5) De ninguna manera, sino (que lo harás) sustituyendo en el alma que deseas salvar, el lugar de los bienes que antes había, otra riqueza divinizante y aportadora de vida eterna; la disposición conforme al mandato de Dios a cambio de la cual obtendrás la retribución y el honor, y la salvación

68 Sobre las acepciones de $\pi \omega \lambda \epsilon \iota \nu$ (vender): F. PRIngSheIM, Greek Law of Sale (Weimar 1950) 97-98; 159.

${ }^{69}$ La doble corrección [ov] <ov> propuesta en una edición de 1816 fue aceptada por STÄHLIN, BKV (2) 8, 249 n 1. Sobre su fundamentación: U. WICKERT, «Bemerkungen zu Klemens von Alexandrien»: ZNW 50 (1959), 123-127. RITTER [n 25] ZKG 86 (1959) 16 n 87. 
sin fin y la eterna incorrupción. (6) De esta forma vendes bien los bienes, los abundantes y superfluos y que te excluyen del cielo, permutándolos por los que pueden salvar. Que retengan aquellos $[=$ los bienes temporales] los pobres según la carne que carecen de éstos [= los bienes capaces de salvar]. Tú por el contrario, habiendo tomado a cambio la riqueza espiritual, que tengas desde ahora un tesoro en el cielo ${ }^{70}$.

La interpretación de Clemente resulta excesivamente forzada sobre todo en una época como la actual. En algún punto se aprecia incluso algún exceso retórico, por ejemplo al presentar como aberrante el obtener dinero por la venta de bienes como si ésta tuviese por finalidad en el contexto un enriquecimiento patrimonial y no el dar el producto a los pobres.

Dentro de ese proceso de espiritualización Clemente da un concepto de pobreza muy distinto del económico-social. Esa tendencia a espiritualizar el concepto se aprecia ya, aunque con un sentido muy distinto del de Clemente, en los numerosos pasajes del Antiguo Testamento en que aparece la antes mencionada mística de la pobreza, donde bajo el término pobres se engloban todos los oprimidos y se presume que tienen su esperanza puesta en Yavé. Aparece también probablemente (y esta vez en sentido parecido al de Clemente) en la primera bienaventuranza del Evangelio de Mateo (Mt 5, 3), donde la especificación Tü $\pi \nu \in U ́ \mu a T \iota$ puede ser muy bien una adición secundaria al original probablemente conservado en el Evangelio de Lucas (Lc 6, 20) ${ }^{71}$ : de esa forma los bienaventurados no son simplemente los pobres sino los pobres de espíritu. Clemente se apoya expresamente en esa puntualización (Div 16,$3 ; 17,4)$ y la lleva mucho más adelante. Entre los varios pasajes en que da su concepto espiritualizado de pobreza-riqueza, cabe destacar los siguientes:

Div 16, 3 (GCS 17, 170).

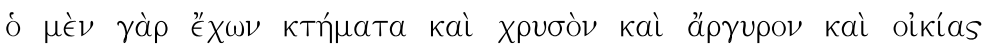

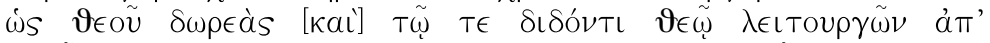

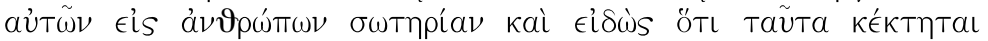

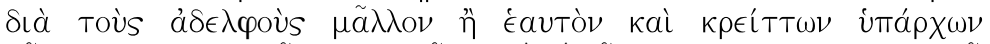

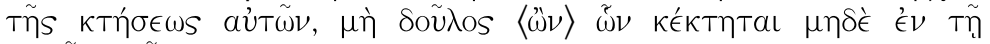

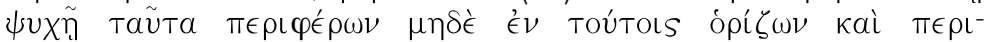

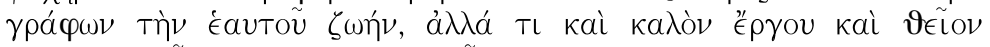

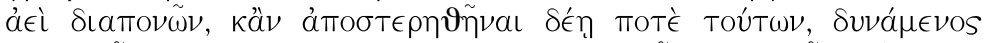

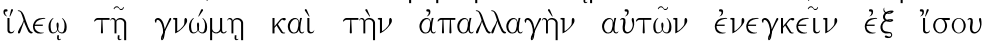

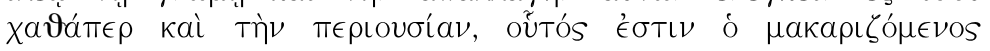

70 Sobre este pasaje: WicKeRT [n 69] ZNW 50 (1959) 123-128.

71 Sobre esta posible adición: Dupont, Béatitudes [n 9] 79-83. 


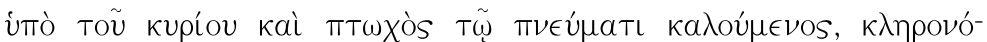

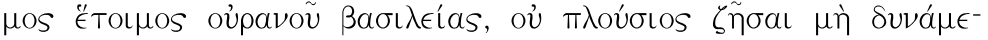
VOS.

El que tiene bienes y oro y plata y cosas como don de Dios y sirve con ellas a Dios que se las dio, y consciente de que ha adquirido estas cosas en razón de sus hermanos más bien que en razón de sí mismo, y tiene el dominio (interno) de la posesión de las riquezas, y no es esclavo de las cosas que posee, ni las tiene constantemente en el alma, ni limita y circunscribe a ellas su vida, sino que constantemente se esfuerza en alguna obra buena y divina, y en el caso de que fuese privado de ellas, es capaz de sobrellevar su privación con la misma serenidad que su presencia, ese es el proclamado bienaventurado por el Señor, y llamado pobre de espíritu, ya preparado como heredero del reino de los cielos; no el rico que no puede alcanzar la vida (eterna).

Clemente precisa exactamente en este pasaje las cualidades positivas y negativas que ha de tener la pobreza de espíritu compatible con la propiedad y tenencia de riquezas. Son las siguientes: (a) tenerlas como don de Dios, (b) servir con ellas a Dios, (c) tener conciencia de su función social, (d) no dejarse dominar internamente por ellas, (e) ser capaz de sobrellevar con serenidad su pérdida. Todas estas ideas aparecen con diversos matices en numerosos pasajes del Antiguo Testamento ${ }^{72}$, de pensadores judíos y paganos anteriores a Clemente ${ }^{73}$ y en el Nuevo Testamento $^{74}$. Los dos últimos puntos reflejan dos ideas fundamentales de la

72 En el AT, junto a la antes mencionada crítica de la riqueza sobre todo por los Profetas, hay algunos pasajes en los que se apunta la idea de que la riqueza la da Dios, y de que quien la tiene debe ayudar con ella a los necesitados. Además de las conocidas afirmaciones de Job (Job 29, 12-16; 31, 14-25), cabe destacar una de las unidades parenéticas intercaladas en el Deuteronomio, donde se exhorta a los israelitas a no olvidar que los bienes materiales les han sido dados por Dios (Dtn 8, 1-20). Sobre el origen y carácter de estas unidades parenéticas: H.D. Preuss, Deuteronomium (Darmstadt 1982) 95-103. Visión general de la actitud (o actitudes) que aparece en el AT sobre la riqueza en: F. HAUCK-W. KASCH, «ா入оuтOS»: TWNT 6, 321-324, quien señala además la insistencia con que la literatura sapiencial hace referencia al problema de teodicea planteado por el fenómeno frecuente de la mala conducta y buena fortuna de muchos ricos.

${ }^{73}$ Rica información sobre la ética de la riqueza en el mundo antiguo en: BogAERT [n 2] RAC 9, 824-829; 839-842.

74 Además de los pasajes citados expresamente por Clemente, hay que mencionar también la parábola de los talentos en sus diversas versiones (Mt 25, 14-30; Lc 19, 11-27). Sobre el probable sentido originario (escatológico) de la parábola: A. JÜLICHER, Die Gleichnisreden Jesu ${ }^{2}$ (Tubinga 1910) 2, 472-495, J. Jeremias, Die Gleichnisse Jesu ${ }^{10}$ (Gotinga 1884) 55-60. Clemente trata el tema en Strom 1, 3, 1-2 (GCS 15 [Clem 2] 4 y entiende la parábola como una explicación de la obligación que tiene todo el que recibe dones de Dios, de utilizar esos bienes en provecho de los demás. Para las líneas generales (y su evolución) de la actitud del NT sobre la riqueza: Hengel, Eigentum [n 9] 31-68. 
ética estoica de Clemente (indiferencia y dominio de las pasiones) que ya se han visto antes ${ }^{75}$.

En contraposición a las cualidades que debe reunir el pobre de espíritu, Clemente describe la codicia, de la que los ricos deben estar libres, ya que de lo contrario no tendrían acceso al reino de los cielos (Div 17, 1). Por tanto Clemente distingue dos tipos de ricos (en el sentido de personas con abundantes bienes materiales) según sea su disposición interna, y aplica el mismo razonamiento a los pobres. Entre éstos hay los que el Salvador proclamó bienaventurados y en el Evangelio de Mateo son calificados expresamente como pobres de espíritu ( $\pi T \omega \chi \mathrm{X}$

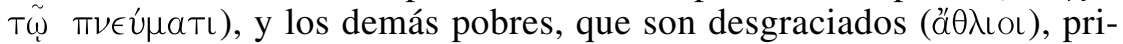
vados de bienes materiales, pero no partícipes de la justicia de Dios

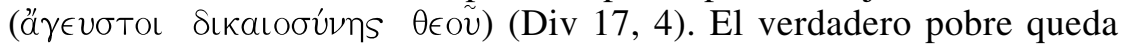
descrito de la siguiente manera.

Div 26, 6 (GCS 17, 177)

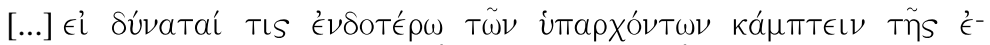

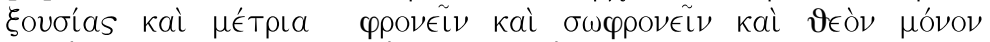

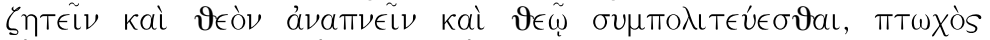

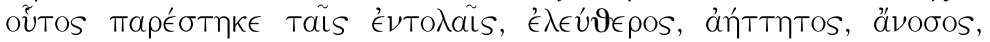

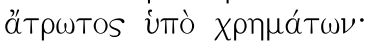

[...] si alguno puede doblegar internamente el poder de las riquezas y valorar las cosas con moderación y ser sobrio y buscar sólo a Dios y anhelar a Dios y vivir en comunidad con Dios, ese es pobre conforme a los mandamientos, libre, invicto, sano, no vulnerable por las riquezas.

En otro pasaje oscuro en su formulación y de terminología vacilante, Clemente deja clara la contraposición pobre-rico en su concepción de la perfección cristiana:

Div 19, 1-2 (GCS 17, 171-172).

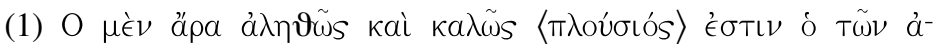

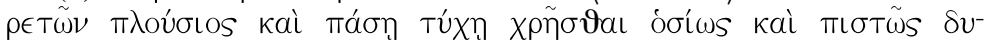

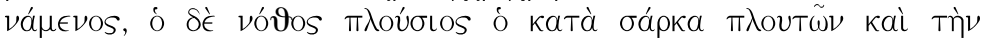

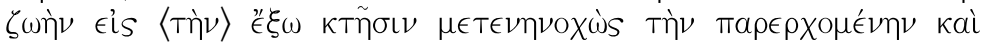

75 En la Biblia, además de la indiferencia ante la pérdida de la riqueza, que aparece paradigmáticamente presentada en Job 1, 6-22, en el NT se exhorta con frecuencia a liberarse de la preocupación excesiva por los bienes materiales con fundamento en la confianza en Dios y en la concepción escatológica de su inminente caducidad. Ver sobre este

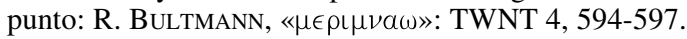




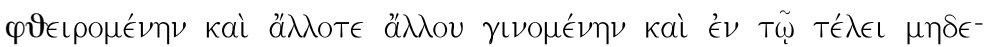

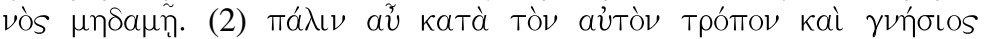

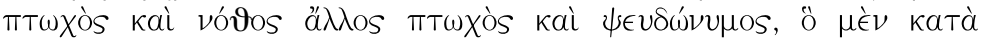

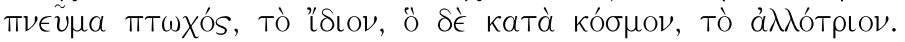

Así pues el verdadero y auténticamente rico es el rico en virtudes y capaz de afrontar santa y fielmente cualquier situación. Por el contrario, el falso rico es el que tiene abundantes riquezas según la carne y ha orientado la vida a los bienes de fuera que desvían y corrompen y cambian de mano, y al final no son de nadie. (2) Y de la misma forma se da el pobre legítimo y el bastardo y falso pobre. El propiamente pobre lo es en espíritu, impropiamente lo es el pobre según el mundo ${ }^{76}$.

En todos estos pasajes Clemente razona de forma perfectamente lógica y congruente con su modo de concebir la perfección del cristiano como un constante avance interno e individual del hombre que, despojando su alma de pasiones, se acerca a Dios. Por ninguna parte aparece referencia alguna expresa al marco social de injusticia, ni la preferencia por los pobres y oprimidos tan manifiesta en los Profetas, en los Salmos, en los Sinópticos y en otros escritos como la Carta de Jacobo, que acabó formando parte del Nuevo Testamento.

Clemente continúa su discurso dando una explicación sorprendente de lo que el Evangelio dice sobre la reacción del joven rico consultante y de los discípulos de Jesús presentes en el diálogo. Del consultante dice el Evangelio de Marcos que «sombríamente contrariado por estas palabras se marchó apenado, porque poseía muchos bienes» (Mc 10, 22) ${ }^{77}$. Según Clemente el joven no entendió bien a Jesús: no comprendió cómo se podía ser al mismo tiempo pobre y rico en el sentido arriba expuesto, y por ello se retiró triste al haber confundido lo difícil (evitar que el alma sea arrastrada y absorbida por las riquezas) con lo imposible (Div 20, 12).

Según el Evangelio, los discípulos de Jesús, ante las observaciones de su maestro sobre la dificultad de que se salvasen los ricos (Mc 10, 23-25), «se asombraban con temor ante esas palabras»y «se llenaban cada vez más de temor diciendo entre sí: ¿quién puede salvarse?» (Mc 10, 24-25). Clemente comenta audazmente que ese temor deriva

76 Sobre el sentido de esta última frase de Div 19, 2: WiCKERT [n 69] ZNW 50 (1959) 123-123; RITTER [n 25] ZKG 86 (1975) 16 n 87.

77 Mc 10, 22 presenta la reacción del joven como un doloroso rechazo de la invitación de Jesús al seguimiento incondicional. Sobre el sentido histórico de la ruptura incluso de los más elementales lazos familiares exigida por Jesús para su seguimiento (Mt 8, 21-22; Lc 9, 57-62; 14, 26 etc): HeNGEL, Nachfolge [n 50] 8-17. 
precisamente de que habían entendido muy bien las palabras de Jesús y se daban cuenta de que, aunque habían abandonado sus bienes para seguirle, esa renuncia era indiferente para su salvación (Div 20, 2-6). Como ya he indicado en otros pasajes, Clemente había puesto de relieve la misma idea e incluso había apuntado los peligros que conlleva la carencia de bienes temporales en orden a obtener la perfección (Div 12, $4-5 ; 15,2-3)$. La conclusión que de todo ello saca es que la renuncia de las cosas temporales sólo es estrictamente obligatoria para los que se sienten internamente dominados por la avidez (Div 24, 1). A ellos aplica varios pasajes evangélicos: por extensión, el que prescribe el odio a los miembros de la familia ( $\operatorname{Lc} 14,26)$, entendiendo que eso sólo debe hacerse cuando los parientes son un impedimento para la salvación (Div 23, 2-24, 1); directamente, el que aconseja amputarse una mano o un pie o sacarse un ojo, cuando sean un obstáculo para alcanzar la vida eterna (Mt 5, 29-30; Mc 9, 43-47) (Div 24, 2-3).

Por último, a título de curiosidad, es interesante examinar el tratamiento que Clemente da al dicho de Jesús sobre el camello y la aguja (Mc 10, 25 par). Es bien conocido el intento (muy posterior a Clemente) de suavizar la hipérbole de la comparación mediante la corrección кá $\mu \iota \lambda$ os (= calabrote) en lugar de кá $\mu \eta \lambda o s$ que aparece tarde en algunos manuscritos. Clemente sólo hace referencia de pasada al dicho de Jesús en un pasaje estilísticamente duro (Div 26, 8-27-1) constituido por tres fases introducidas cada una en tercera persona del singular cuyo sujeto es el camello, o más exactamente el dicho sobre el camello y la aguja. He aquí el texto de Clemente seguido de una traducción que no puede menos de ser estilísticamente dura al pretender reflejar fielmente la formulación de Clemente ${ }^{78}$.

Div 26, 8-27, 1 (GCS 17, 177)

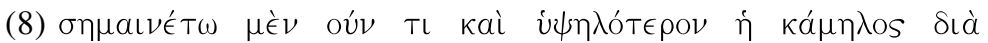

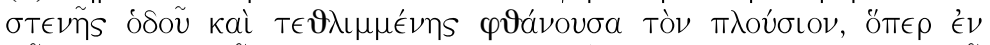

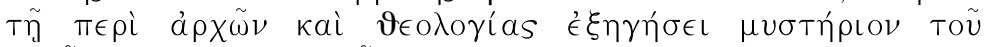

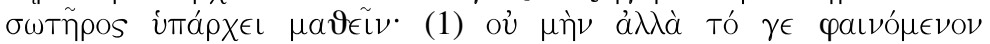

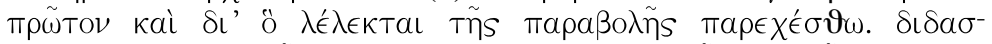

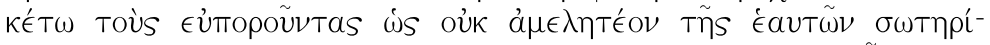

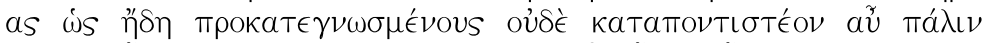

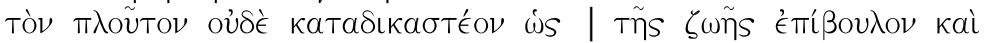

78 Clemente recurre a una formulación retórica construida gramaticalmente en imperativo, que resulta muy dura en las lenguas modernas. Suavizan estilíticamente la traducción sin alterar el sentido: STÄHLin [n 33] BKV (2) 8, 257-258; ButTERWORTH [n 33] 327. 


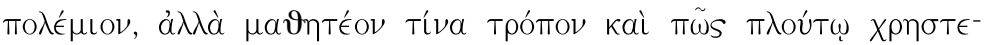

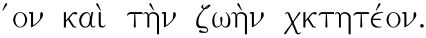

(8) Por tanto el camello que lleva la delantera al rico por el camino estrecho y áspero, signifique (= ha de tener un significado) algo más sublime, cuyo misterio se puede aprender en la explicación sobre los principios de la teología. (1) No represente (= no ha de significar) lo primero que aparece en la comparación que se ha utilizado como manera de hablar. Enseña a los ricos cómo no hay que desentenderse de su salvación, como si estuviesen ya condenados, ni tampoco hay que arrojar al fondo del mar la riqueza como insidiosa o enemiga de la vida (eterna), sino que hay que aprender de qué forma y cómo se ha de usar de la riqueza y obtener la vida.

Clemente afirma que el dicho de Jesús tiene un sentido más eleva-

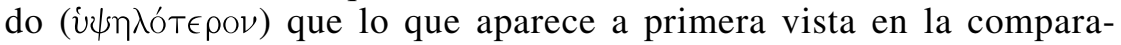
ción utilizada como medio de expresión. Omite la explicación de ese

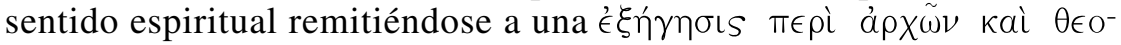
$\lambda o \gamma i$ as. Con frecuencia se han entendido estas palabras como la referencia a una obra actualmente no existente (¿perdida?, ¿proyectada y no escrita?) a la que aludirían también otros pasajes de los Stromata y cuyo título sería Tratado sobre los principios y la teología. Sin embargo puede tratarse simplemente de la referencia a otro tipo de explicaciones sobre temas teológicos, distintas en su género de la forma homilética del opúsculo sobre la riqueza ${ }^{79}$. No hay datos para vislumbrar por donde iría la explicación alegórica. Podrían tal vez servir de orientación las reflexiones de Orígenes sobre el mismo tema en que ve indicios de explicación en la deformidad anatómica del camello y en su calificación de animal impuro aceptable por ser rumiante, pero inmundo por solípedo ${ }^{80}$. En nuestro pasaje Clemente, lo mismo que más tarde Orígenes en el pasaje recién aludido, relaciona el dicho de Jesús sobre el camello y la aguja con otro en que Jesús contrapone la puerta estrecha y el camino áspero que conducen a la vida eterna, a la puerta ancha y el camino amplio que conducen a la perdición (Mt 7, 13-14) en una imagen con abundantes precedentes en la doctrina moral judía ${ }^{81}$.

79 Clemente menciona ese tratado en otras dos ocasiones: (Strom 3, 13, 1 [GCS 15, 201]; 3, 21, 2 [GCS 15, 205]), de los que no puede deducirse exactamente su género literario. Hipótesis sobre el tema en: ButTERworth [n 33] 327d; STÄHLIn [n 33] BKV (2) 7, 40.

80 Orig, Cels 6, 16 (SC 147, 618) con referencia a Lev 1, 4.

81 Sobre la doctrina de los dos caminos: KRETSChMAR Beitrag [n 11] 158-160; M.J. SugGS, «The Christian Two Ways Tradition» en: Essays in Honor of A.P. Wikgren (Leiden 1972) 63-74; W. RORDORF, «Un chapitre d'éthique judéo-chrétienne»: RSR 60 (1978) 110-115. 


\section{Riqueza y obligación de caridad}

Lo expuesto hasta aquí sobre la espiritualización por Clemente de los conceptos de pobreza y riqueza y su encuadramiento en un ideal de perfección marcadamente intelectualista e individualista, podía dejar la impresión de que Clemente al armonizar filosofía y evangelio había sacrificado un elemento esencial del mensaje ético, cristiano que es el amor al prójimo. Esta imagen sería totalmente falsa.

En uno de los pasajes antes transcritos afirmaba Clemente que los bienes son don de Dios para servicio de los hombres, y que deben ser poseídos más en razón de los hermanos que de uno mismo (Div 16, 3).

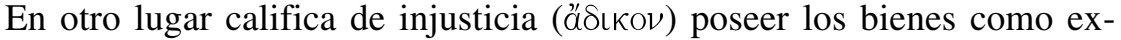
clusivamente propios y no participarlos con los necesitados (Div 31, 6) ${ }^{82}$. Antes de llegar a esa conclusión hace una enumeración de los principales pasajes de los Sinópticos en que se manda o aconseja ayudar al prójimo (Mt 25, 34-45 [Div 30, 2-4]; Mt 10, 41-42 [Div 31, 4]; Lc 16, 9 [Div 31, 5] y sobre todo Mc 12, 30 y Lc 10, 27-29, en que se condensa la ética cristiana en el cumplimiento del doble mandamiento de amar a Dios y amar al prójimo [Div 27, 3-5]). Clemente desarrolla puntos importantes de la actividad benéfica, a la que está obligado todo cristiano que tenga riquezas ${ }^{83}$. Dentro de los límites de este trabajo sólo cabe mencionar algunos de esos puntos sin poder entrar a fondo en algunos de los problemas que plantean.

Un primer punto importante es la determinación de quiénes son los destinatarios de esa beneficencia. Sería muy interesante (pero imposible en este trabajo) detenerse a examinar el concepto de prójimo en el

82 Una cierta finalidad social de la riqueza aparece apuntada (aunque sin un desarrollo práctico sistemático) en diversos escritores griegos y latinos, sobre los que da abundante información: BogAeRT [n 2] RAC 9, 824-829; 839-842. Clemente al tratar de la riqueza en su Pedagogo, desarrolla el principio de la finalidad social de la riqueza con las siguientes ideas: (a) Todas las cosas han sido dadas por Dios a los hombres (con base en Mt 6, 33) (Paed 2, 120, 2); (b) Todas las cosas son comunes (Kolva ouv

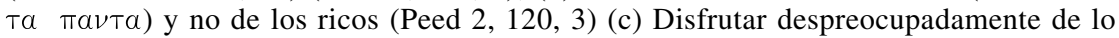

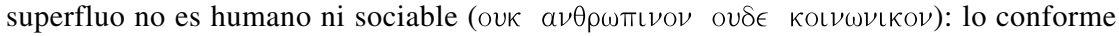

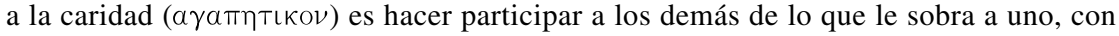
base en el precepto evangélico de amar al prójimo como a uno mismo (Paed 2, 120,4). (d) Dios ha dado a los hombres poder de usar las cosas, pero sólo dentro de los límites

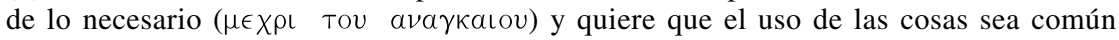
(

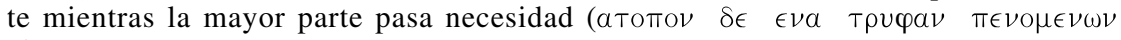
$\pi \lambda \epsilon \operatorname{lo} \nu \omega \nu)$ : Mucho mejor que vivir en la riqueza es hacer el bien a muchos (Paed 2, $120,6)$.

${ }^{83}$ Sobre la caridad y la beneficencia en Clemente: VöLKER [n 24] 479-502; 550-551. 
Antiguo y en el Nuevo Testamento ${ }^{84}$. Clemente censura a los judíos por haberlo entendido de forma demasiado restringida (Div 28, 2). Luego para determinar el concepto recurre a la parábola del buen samaritano (Lc 10, 30-37) (Div 28, 3-4), pero la interpreta como alegoría e identifica al buen samaritano con Cristo (Div 29, 2-4), con lo que el concepto prójimo queda sin aclarar ${ }^{85}$. Reproduciendo una idea típica de la ética estoica, Clemente recomienda que al dar se elija a quien es digno de recibir (Div 31, 7-9), pero hace notar sin embargo que, en la práctica, puede ser peligrosa tal selección, ya que podría uno equivocarse, por lo que es preferible dar a todo el que pida (Div 33, 2-3). Señala también el peligro de fijarse solamente en los rasgos externos (Div 33, 5-6) ${ }^{86}$.

${ }^{84} \Pi \lambda \eta \sigma \iota \nu$ (= prójimo) es morfológicamente un acusativo adverbial del adjetivo $\pi \lambda \eta^{-}$ $\sigma \operatorname{los}$ (= cercano, próximo) que se utiliza como substantivo (o $\pi \lambda \eta \sigma \iota \mathrm{\nu}=$ el que está cerca) (W. Bauer-K. Aland-B. Aland, Griechisch-deutsches Wörterbuch zu den Schriften des Neuen Testaments und der frühchrictlichen Literatur ${ }^{6}$ [Berlín 1980] 1351-1352). Los LXX tradujeron con tal término varias palabras hebreas que básicamente designaban las personas vinculadas entre sí por la Alianza del pueblo de Israel con Yavé. Aunque originariamente el término se entendía como restringido a los miembros del Pueblo y a los prosélitos plenamente tales (con exclusión por tanto de los extranjeros, samaritanos, etc.), ya en la época de Jesús había en el Judaísmo tendencias a ampliar la extensión del concepto y a incluir en el precepto de amar al prójimo a todos los hombres. Por otra parte existían corrientes que excluían de tal precepto a los enemigos personales o a los de grupo (BILLERBECK [n 2] 19,

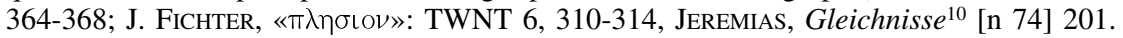
En la predicación de Jesús y en todo el NT el precepto de amar al prójimo ocupa un lugar central y queda inequívocamente extendido a todo ser humano con el que existencialmente

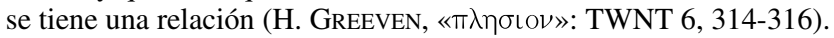

85 El objetivo originario de la parábola del buen samaritano fue con toda probabilidad poner de relieve a través de la narración que el precepto de amor al prójimo carecía de todo límite basado en diferencias que pudieran darse entre personas o grupos a los que pudieran pertenecer el necesitado de ayuda y el que podía ayudar: Jesús dejaba claro en la narración de la actitud del para los judíos execrable samaritano que, cuando un hombre se halla en necesidad, hay que ayudarle, independientemente de la diferencia y distancia social y religiosa (en el sentido más amplio de ambos términos) que se dé entre el posible benefactor y el necesitado: JEREMIAS, Gleichnisse $e^{10}$ [n 74] 203). La alegorización de la parábola por Clemente es el producto de su extremada preferencia por el sentido espiritual en la interpretación de la Escritura (ver n 60). Ejemplos de interpretaciones alegóricas análogas a las de Clemente en: JÜLICHER, Gleichnisreden ${ }^{2}$ [n 74] 2, 597-598.

${ }_{86}$ Abundante material sobre las ideas de la ética griega y romana acerca de quiénes debían ser los destinatarios de la beneficencia en: H. BOLKESTEIN, Wohltätigkeit und Armenpflege im vorchristlichen Altertum (Utrecht 1939 = Nueva York 1979) 95-101; 118-132; 295-306. Clemente, con base en un principio extendido en la ética griega de diversas escuelas (Arist, EN 4,2,1 [1120 a 23-27]; SVF 3, 262), mantiene en sus Strommata que la beneficencia perfecta debe tener previamente en cuenta la persona del presunto beneficiario y sólo debe ejercitarse con los que son dignos de recibir (Str 7, 69, 1-3.7 [GCS 17 (Clem 3) 4950]). En Div mantiene todavía ese principio cuando advierte que no se manda en el Evangelio dejarse importunar $(\epsilon \nu \circ \chi \lambda \epsilon \sigma \theta a \mathrm{~L})$ por los pedigüeños, sino buscar uno mismo a los que pien- 
En un pasaje cuya introducción es oscura por lo conciso de su formulación, presenta Clemente como norma para determinar el destinatario adecuado un dicho que parece atribuido a Jesús aunque no está introducido por la palabra pnoí (= «dice», se sobrentiende el Señor) como suele ser usual en tales casos: «Daré no sólo a los amigos sino a los amigos de los amigos» (Div 33, 1) ${ }^{87}$. En todo caso fija como destinatarios de la beneficencia a los miembros de la comunidad cristiana

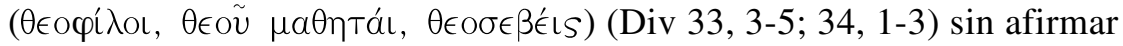
nunca expresamente que la caridad no deba extenderse a los no-cristianos.

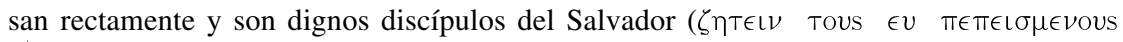

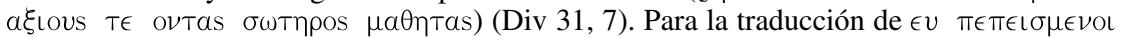
como «los que piensan rectamente» en el sentido de cristianos: LAMPE, Lexicon [n 42 ] 1055. A pesar de esta afirmación restrictiva sobre los destinatarios de la beneficencia cristiana, Clemente aduce pocas líneas más tarde el pasaje evangélico que manda o recomienda dar a todo el que pida (Lc 6, 30), y añade que tal principio es mejor, ya que muestra la generosidad de Dios (Div 31, 9). En Div 33, 2-6 Clemente da una confirmación racional (peligro de equivocarse por las apariencias) y otra ético-teológica (abstenerse de juzgar a los demás) de tal principio ético.

${ }^{87} \mathrm{El}$ pasaje es sumamente oscuro. En el contexto inmediatamente precedente (Div 32, 1-6) Clemente pondera la grandeza de los bienes eternos que el cristiano puede lograr por el ejercicio habitual de la caridad con el prójimo. A continuación aparece el pasaje que aquí nos interesa, considerado y presentado como párrafo aparte en las ediciones impresas. El pasaje (Div 33, 1) consta de tres elementos que para mayor claridad presento separados:

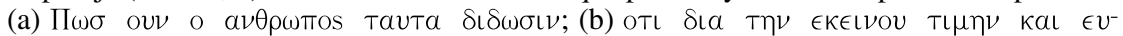

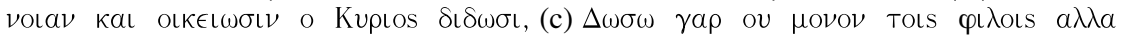
kal Tols $\varphi$ i $\lambda$ ols $T \omega \nu$ pi $\lambda \omega \nu$. El elemento (a) es indudablemente una pregunta, en la que el sujeto ( $\alpha \nu \rho \rho \omega \pi \mathrm{O})$ parece designar al hombre en general, con lo que el sentido de la pregunta sería: «por tanto ¿cómo da (= o puede o debe dar) el hombre estas cosas (= los bienes con los que ejercita su beneficencia)?». El segundo elemento (b) es una respuesta extrañamente introducida por la partícula otı, probablemente debido a la concisión habitual

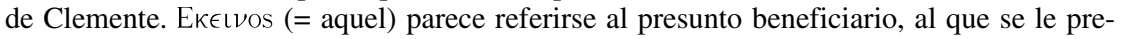
senta alternativamente siempre en genitivo como sujeto de la estima $(\tau \iota \mu \eta)$, objeto de la benevolencia $(\epsilon \cup \nu \circ \iota \alpha)$ del Señor y unido a él íntimamente (oเ $\epsilon \iota \omega \sigma \iota s)$. Parece indicar Clemente que estas son las líneas fundamentales tenidas en cuenta por Dios al conceder sus beneficios. En la edición de Migne se omite este segundo elemento (b) (PG 9, 637-638). STÄHLIN [n 33] BKV (2) 8, 264 traduce libremente mediante una paráfrasis que recoge fielmente el sentido de la frase, y cuya traducción sería: «porque Dios concede sus dones por razón de su estima de aquel hombre, y por razón de su benevolencia hacia él y de su cercana amistad para con él». BUTTERWORTH [n 33] 339 mantiene en su traducción la concisión del texto. El tercer elemento (c) es una explicación de (b) y generalmente es considerado como un agraphon, aunque falta el término introductorio ( $\varphi \eta \sigma \iota$ o equivalente) que lo presente explícitamente como tal. En este sentido: A. JÜLICHER, Rec. Köster: TLZ 19 (1984) 20; STÄHLIN [n 33] BKV (2) 8, 265; ButTERWORTH [n 33] 339. El sentido del presunto agraphon es claro: «Daré no sólo a los amigos, sino a los amigos de los amigos». Clemente lo toma como criterio directivo a seguir por el cristiano en el ejercicio de la caridad. 
Finalmente Clemente exhorta a dar con alegría tomando como base un pasaje de San Pablo (2 Cor 9, 6-7) (Div 31, 9) y a hacerlo con constancia y satisfacción siendo conscientes de la desproporción existente entre el valor y mérito de las obras de caridad por un lado y por otro el escaso sacrificio que implica su realización (Div 32, 1-6) ${ }^{88}$.

Clemente añade unas consideraciones sobre el relativamente escaso número (pero excelente en su calidad) de quienes siguen las orientaciones que ha ido exponiendo (Div 34-36); sobre la importancia teológicoreligiosa del ejercicio de la caridad (Div 37-38), y sobre la posibilidad de que quien no las ha seguido, cambie de vida (Div 39-40). A continuación aconseja a quien quiera hacerlo que se acoja a la dirección de un miembro de la comunidad cristiana destacado en su avance hacia la perfección (Div 41). Finalmente, Clemente añade una narración, a la que califica de $\mu v \theta$ os ov $\mu v \theta$ os, lo que podría traducirse aproximadamente como «leyenda no falta de sentido» ${ }^{89}$. En ella narra un episodio legendario de la vida de San Juan Evangelista en sus últimos años, en la que se pone de manifiesto la posibilidad de la conversión aun de aquel que ha cometido los mayores delitos (Div 42, 1-19). Clemente termina la narración con una breve doxología, con la que concluye su obra (Div 42, 1,20).

\section{Conclusión}

Al tratar de resaltar los rasgos fundamentales de la actitud de Clemente ante la riqueza, hay que destacar en primer lugar el gran esfuerzo realizado (y avance logrado) en la racionalización del tema. Se da en él también una enorme labor de adaptación de los principios del Nuevo Testamento a unas circunstancias culturales, económicas y sociales notablemente distintas sobre todo de las que rodearon la vida de Jesús. Como se ha visto antes, Clemente no fue el iniciador de ese proceso de adaptación que venía produciéndose gradualmente desde mucho antes en diversos sectores del pensamiento cristiano. Sí fue en cambio el primero (al menos el primero actualmente conocido) en reflexionar a fondo sobre el tema y en recurrir sistemáticamente para su tratamiento a la combinación de la revelación cristiana con la ética ecléctica de su tiempo de signo marcadamente estoico.

88 Sobre la idea de dar con alegría, que Clemente apoya en una recomendación de San Pablo (2Cor 9, 6-7): E.F. BRUCK, «Ethics versus Law»: Traditio 2 (1944) 97-107 = IDEM, Über römisches Rech im Rahmen der Kulturgeschichte (Berlín 1954) 101-115.

89 Sobre la calificación $\mu v \theta$ os ov $\mu v \theta$ os: WiCKERT [n 69] ZNW 50 (1959) 129-132. 
En esa tarea de racionalización, adaptación y sistematización hay logros y avances importantísimos, pero se aprecia una fuerte orientación individualista (no egoísta) y una falta de sensibilidad para la situación de miseria en que sin culpa propia se hallaba un gran sector de la sociedad de su tiempo. El pobre y oprimido no aparece en Clemente como el destinatario preferente del mensaje cristiano, a diferencia de muchos escritos del Nuevo Testamento (sobre todo los Evangelios Sinópticos), en los que esa preferencia no parece ser algo puramente condicionado a las circunstancias históricas.

Es interesante señalar que la actitud racional de Clemente sustancialmente y con variantes es la que se impuso en el cristianismo, pero sin llegar a desplazar otras actitudes basadas en factores de sensibilidad $\mathrm{y}$ generosidad que con frecuencia trascienden lo puramente racional y que también están presentes en el Evangelio. Basta recordar la reacción del egipcio Antonio (probablemente el año 271), para quien precisamente la perícopa del joven rico fue decisiva para que emprendiese la vida monástica, con importantísimas consecuencias en la espiritualidad cristiana $^{90}$. Constantemente, con motivos muy distintos y en circunstancias y con variedades muy diversas, el problema riqueza-pobreza ha seguido y sigue apareciendo como no plenamente resuelto a lo largo de la historia del cristianismo.

90 Narración del suceso en: Athan, VitAnt 2 (PG 26, 841-844). Comentario en: R. REITZENSTEIN, Hellenistische Wundererzählungen (Leipzig 1906 = Stuttgart 1963) 56-57; G. BARDY, «Antoine»: DSAM 1, 702-703. 